\title{
Taylor Kuralı Kapsamında Türkiye Cumhuriyet Merkez Bankası Para Politikası Tepkilerinin Belirlenmesi: Doğrusal ve Doğrusal Olmayan Zaman Serisi Analizi (2002:Q1-2019Q:2)
}

The Determination of Monetary Policy Responses of The Central Bank of Republic of Turkey in the Context of The Taylor Rule: Linear and Nonlinear Time Series Analysis (2002: Q1-2019Q: 2)

Ömer YALÇINKAYA ${ }^{1}$

Şekip YAZGAN ${ }^{2}$

Geliş tarihi: 06.09.2019, Kabul tarihi: 21.12.2019, Basım tarihi: 10.05.2020

\section{$\ddot{\mathrm{O}} \mathrm{z}$}

Bu çalışmada, 2002 y1lından bu yana enflasyon hedeflemesi rejimini benimsemiş olan Türkiye Cumhuriyet Merkez Bankası (TCMB) tarafından para politikasının temel aracı olarak kullanılan politika faiz oranlarının belirlenmesinde orijinal ve genişletilmiş Taylor kurallarının geçerli olup olmadığının ampirik olarak incelenmesi amaçlanmaktadır. Bu amaçla çalışmada orijinal ve genişletilmiş Taylor kurallarının TCMB açısından 2002:Q1-2019Q:2 dönemindeki geçerliliği, doğrusal ve doğrusal olmayan zaman serisi analizi kapsaminda ekonometrik olarak incelenmektedir. Çalışma sonucunda, doğrusal ve doğrusal olmayan formlarda orijinal ve genişletilmiş Taylor kurallarının inceleme döneminde TCMB açısından enflasyon, üretim ve döviz kuru açıkları itibariyle geçerli olduğu tespit edilmiştir. Bu sonuçlar, Türkiye ekonomisinde enflasyon hedeflemesi rejiminin benimsendiği 2002-2019 döneminde TCBM tarafından para politikası stratejilerinin orijinal ve genişletilmiş Taylor kuralları kapsamında tasarlandığını ve para piyasası politika faiz oranlarının enflasyon, üretim ve döviz kuru açıklarındaki değişimlerin dikkate alınmasıyla belirlendiğini göstermektedir.

Anahtar Kelimeler: Taylor Kuralı, Kurallı Para Politikaları, TCMB, Doğrusal ve Doğrusal Olmayan Zaman Serisi Analizi.

JEL Kodlar1: E58, C01, C22

\begin{abstract}
Abstact
In this study, it is aimed to empirically examine whether the original and extended Taylor rules are valid in determining policy interest rates used as the main tool of monetary policy by the Central Bank of the Republic of Turkey (CBRT), which has adopted the inflation targeting regime since 2002. For this purpose, the validity of the original and extended Taylor rules for the CBRT in the 2002: Q12019Q: 2 period is examined econometrically in the context of linear and nonlinear

\footnotetext{
${ }^{1}$ Ağr1 İbrahim Çeçen Üniversitesi, İ.İ.B.F. İktisat Bölümü, Doç. Dr.

omeryalcinkaya84@hotmail.com

https://orcid.org/0000-0002-1210-2405

2 Ağrı İbrahim Çeçen Üniversitesi, İ.İ.B.F. İktisat Bölümü, Dr. Öğretim Üyesi

syazgan@agri.edu.tr

https:// orcid.org/0000-0003-1006-668X
} 
time series analysis. As a result of the study, it was found that the original and extended Taylor rules in linear and nonlinear forms were valid for inflation, production and exchange rate deficits for the CBRT during the review period. These results indicate that the monetary policy strategies were designed by the CBRT within the scope of the original and extended Taylor rules and determined by considering changes in inflation, production and exchange rate deficits of money market policy interest rates, in 2002-2019 period the adoption of inflation targeting regime in Turkey's economy.

Keywords: Taylor Rule, Regular Monetary Policies, CBRT, Linear and Nonlinear Time Series Analysis.

JEL Codes: E58, C01, C22

\section{Giriş}

Bilindiği üzere, para politikaları para arzı, faiz oranı, döviz kuru vb. gibi üretim (hâsıla) ve enflasyon düzeyi üzerinde dolaylı veya dolaysız bir şekilde etkili olan makroekonomik göstergelerin merkez bankalarınca kontrolüne dayanan stratejilerin bütününü oluşturmaktadır. Kısa dönemde etkilerini enflasyon ve üretim düzeyi üzerinde gösterebilen para politikaları uzun dönemde ise ücretlerin ve fiyatların esnekliğinden dolayı sadece enflasyon düzeyi üzerinde etkili olabilmektedir. Bu nedenle, merkez bankalarınca para politikalarının/para politikası araçlarının kısa dönemde enflasyon ve üretim düzeyine ilisskin temel hedefler arasında denge gözetilerek tasarlanması gerekmektedir (TCMB, 2013a:11). Bununla birlikte, son ylllarda merkez bankalarının para politikalarını kısa dönemde salt enflasyonu temel alacak bir şekilde tasarlamalarının ve para politikası araçlarını enflasyonu kontrol altına alabilecek bir şekilde kullanmalarının gerekli olduğu yönünde genel bir kabul bulunmaktadır (Özçam, 2004:1; Caporale vd.,2018: 307).

$\mathrm{Bu}$ doğrultuda günümüzde amaç ve araç bağımsızlığına kavuşturulan merkez bankaları, para politikalarını temelde fiyat istikrarının sağlanıp sürdürülmesini hedefleyecek şekilde tasarlamakta ve para politikası araçlarını da bu temel hedefi tutturabilecek şekilde kullanmaktadirlar. En genel ifadesiyle enflasyon hedeflemesi olarak adlandirilan bu para politikasi rejiminde, merkez bankaları tarafindan para politikası temel amac1 kapsamında belli bir enflasyon haddi hedefi kamuoyuna ilan edilmekte ve para politikası araçlarının bu temel hedefin tutturulmasına yönelik olarak kullanımı piyasa katılımcilarına taahhüt edilmektedir (TCMB, 2005:2; TCMB,2013a:11). 1990'lı yıllardan itibaren fiyat istikrarının sağlanıp sürdürülmesine odaklanan ve enflasyon hedeflemesi rejimini benimsemiş olan merkez bankaları tarafindan kisa vadeli faiz oranları (para piyasası politika faiz oranları) da bu türden para politikalarının temel aracı olarak kullanım görmektedir. (Akdeniz ve Çatık, 2019: 109). Nitekim kısa vadeli faiz oranlarını para politikası aracı olarak kullanan merkez bankalarının faiz 
kararlarının üretim ve enflasyon düzeyi üzerindeki etkileri, faiz, beklentiler, finansal varlık fiyatları ve döviz kuru kanallarını kullanan parasal aktarım mekanizmasının işlemesiyle gerçekleşmektedir. $\mathrm{Bu}$ nedenle, enflasyon hedeflemesi rejiminde para politikalarının başarısı parasal aktarım mekanizmasının işleyişiyle yakından ilişkili olmakta ve merkez bankaları tarafindan para politikalarının parasal aktarım mekanizmasına işlerlik kazandıracak bir şekilde uygulanmasını gerektirmektedir (TCMB, 2013b:2-6). TCMB, 2013a:11).

Para politikalarının uygulanmasında ise iki farklı yaklaşım bulunmaktadır: Bunlardan birincisi Keynesyen iktisatçılar tarafindan ileri sürülen ve para politikası uygulamalarının merkez bankalarının (politika otoritelerinin) inisiyatifine birakılmasına dayanan basirete dayalı (ihtiyari) para politikası yaklaşımı olarak bilinirken, ikincisi ise Monetarist ve Yeni Keynesyen iktisatçılar tarafindan ileri sürülen ve para politikası uygulamalarının önceden belirlenen kurallara göre ve merkez bankalarının inisiyatifine bırakılmadan yürütülmesine dayanan kurala dayalı (kurallı) para politikası yaklaşımı olarak adlandırılmaktadır. İhtiyari para politikaları uygulamalarında, para piyasalarındaki her bir parasal durumumun farklı bir politika uygulaması gerektirebileceğinden hareket edilmekte ve bu alternatif durumlardaki politikaların uygulanması merkez bankalarının takdir yetkisine bırakılmaktadır. İhtiyari uygulamaların para piyasasında gecikmelere ve zaman tutarsızlığına neden olacağını belirten kurallı para politikaları uygulamalarında ise para piyasalarındaki her bir parasal durum karşısında uygulanabilecek politikalar önceden belirlenmekte ve merkez bankaları tarafindan bu alternatif durumlardaki politikalar inisiyatif alınmadan belirlenen kurallar doğrultusunda yürütülmektedir (Mankiw, 2010: 464-68; Ünsal, 2017: 642-54).

Bununla birlikte, para politikalarının uygulanmasında kurallı yaklaşımlar enflasyon hedeflemesi rejiminin temel ilkeleriyle ve uygulama özellikleriyle daha fazla örtüşmekte ve para politikalarının belirli bir kurala dayalı olarak uygulanması parasal politikalardaki beklenti yönetimini kolaylaştırarak, şeffaflı̆g ve güvenilirliğini artırarak enflasyon hedeflemesi rejiminin başarısını güçlendirmektedir. $\mathrm{Bu}$ nedenle, günümüzde fiyat istikrarının sağlanıp sürdürülmesine odaklanan ve enflasyon hedeflemesi rejimini benimsemiş olan merkez bankaları tarafindan parasal aktarım mekanizmasına işlerlik kazandıran kısa vadeli faiz oranlarının belirlenmesinde genellikle kurala dayalı para politikası yaklaşımları kullanılmaktadır (Ardor ve Varlık, 2014: 47). Kurala dayalı bu para politikası yaklaşımlarından biri olarak önerilen ve John B. Taylor (1993-2001) tarafindan geliştirilen Taylor kuralı, enflasyon hedeflemesi rejimini benimsemiş olan merkez bankalarına enflasyon haddi hedefinde belirli bir sapmanin meydana gelmesi durumunda para politikasinın temel aracı olan kısa vadeli faiz oranlarının belirlenen kriterlere göre hangi yönde 
değiştirilmesi gerektiğini göstermektedir (Taylor, 2001: 263-67). Bu kapsamda, merkez bankalarına enflasyon haddi, üretim düzeyi ve döviz kurlarındaki değişimlerden kaynaklı etkilere k1sa vadeli faiz oranları aracılığılla verilmesi gereken tepkileri (reaksiyonları) gösteren Taylor kuralı, günümüzde enflasyon hedeflemesi rejimini benimsemiş olan merkez bankalarının para politikası uygulamalarını önemli ölçüde şekillendirmektedir (Akdeniz ve Çatık, 2019: 109; TCMB, 2019: 41).

Bu noktadan hareketle çalışmada, 2002 yılından bu yana enflasyon hedeflemesi rejimini benimsemiş olan Türkiye Cumhuriyet Merkez Bankası (TCMB) tarafindan para politikasının temel aracı olarak kullanılan kısa vadeli faiz oranlarının belirlenmesinde Taylor kuralının geçerli olup olmadığının 2002:Q1-2019Q:2 dönemi için ampirik olarak incelenmesi amaçlanmaktadır. $\mathrm{Bu}$ amaçla çalışmada orijinal ve genişletilmiş Taylor kurallanının TCMB açısından geçerliliği, doğrusal ve doğrusal olmayan zaman serisi analizi kapsamında ekonometrik olarak incelenmektedir. Sırasıyla dışa kapalı ve açık ekonomi varsayımlarına dayanan orijinal ve genişletilmiş Taylor kuralları ile doğrusal ve doğrusal olmayan zaman serisi analizi kullanılarak Türkiye ekonomisi özelinde yürütülen çalışma bulgularının, bu konudaki ampirik literatürün gelişimine kullanılan Taylor kuralı varyasyonları, örneklem dönemi ve ekonometrik yöntemler itibariyle katkı sağlayacağı değerlendirilmektedir.

Girişi izleyen birinci bölümde, Taylor kuralının işleyişine yönelik teorik çerçeve açıklanarak, ampirik literatürdeki çalışmalar özetlenmekte ve çalışmanın literatürdeki konumu belirtilmektedir. İkinci bölümde öncelikle araştırmanın verileri tanıtılarak, araştırma verilerinin dönüştürülme süreci açıklanmaktadır. Ardından araştırmanın ekonometrik metodolojisinin açıklandığ1 ikinci bölümde, orijinal ve genişletilmiş Taylor kurallarının TCMB açısından 2002:Q1-2019Q:2 dönemindeki geçerliliğine yönelik doğrusal ve doğrusal olmayan zaman serisi analizlerinden elde edilen bulgular sunulmaktadır. Çalışma araştırma bulgularının tartışılarak politika çıkarımlarının sunulduğu ve literatürdeki çalışmalara yönelik önerilerin bulunduğu üçüncü ve son bölümle tamamlanmaktadır.

\section{Taylor Kuralı: Teorik Çerçeve ve Ampirik Literatür}

Kısa vadeli faiz oranı (para piyasası politika faiz oranı) ile enflasyon haddi, üretim düzeyi (hâsıla) ve döviz kurları arasındaki ilişkileri açıklamak üzere John B. Taylor (1993-2001) tarafindan geliştirilerek para politikalarının belli bir kural dâhilinde sistematikleştirilmesini ve merkez bankalarının para politikası uygulamalarının öngörülmesini sağlayan Taylor kuralının iki farklı versiyonu bulunmaktadır. Bunlardan birincisi, dışa kapalı ekonomilerde kısa vadeli faiz oranı ile enflasyon haddi ve üretim düzeyi arasındaki ilişkileri açıklamak üzere John B. Taylor (1993) tarafindan geliştirilen orijinal Taylor kuralı olarak bilinmektedir (Taylor, 1993: 195-214). İkincisi ise dişa açık 
ekonomilerde kısa vadeli faiz oranı ile enflasyon haddi, üretim düzeyi ve döviz kurları arasındaki ilişkileri açıklamak üzere John B. Taylor (2001) tarafından geliştirilen genişletilmiş Taylor kuralı olarak adlandırılmaktadır (Taylor, 2001: 263-67).

Orijinal Taylor kuralı, merkez bankalarının enflasyonun ve üretimin potansiyel değerlerinden sapması karşısında kısa vadeli faiz oranı üzerinden vermesi gereken para politikası tepkisini yansitmakta ve kısa vadeli faiz oranlarını enflasyon ve üretim açıklarını dikkate alarak belirlemesi gerektiğini göstermektedir (Taylor, 1993: 201-02). John B. Taylor (1993) tanımladığ1 denklemle, merkez bankalarının kısa vadeli faiz oranlarını enflasyonun hedeflenen enflasyondan ve üretimin potansiyel düzeyinden sapmasina göre belirlemesini ve olası bir sapma karşısında kısa vadeli faiz oranlarını değiştirerek para piyasasına müdahale etmesi gerektiğini ortaya koymaktadır (Ball, 1999: 127-28). Kisa vadeli faiz oranınin; reel faiz oranının, enflasyon haddinin ve enflasyon ile üretim açı̆̆ının bir fonksiyonu olduğunu belirten orijinal Taylor kuralı denklemi Eşitlik 1'de gösterilmektedir:

$$
i_{t}=r_{t}+\pi_{t}+\alpha\left(\pi_{t}-\pi_{t}^{*}\right)+\beta\left(y_{t}-y_{t}^{*}\right)
$$

Burada $\left(i_{t}\right)$ ve $\left(r_{t}\right)$ merkez bankaları tarafindan belirlenen para piyasas1 politika faiz oranını ve denge reel faiz oranını temsil etmek üzere denklemdeki terimlerden; $\left(i_{t}\right),\left(r_{t}\right),\left(\pi_{t}\right),\left(\pi_{t}^{*}\right),\left(y_{t}\right)$ ve $\left(y_{t}^{*}\right)$ sirasiyla $\mathrm{t}$ dönemindeki kısa vadeli nominal faiz oranını, reel faiz oranını, gerçekleşen enflasyon haddini, hedeflenen enflasyon haddini, gerçekleşen üretim düzeyini ve potansiyel üretim düzeyini göstermektedir (Taylor, 1993: 20102). Denklemdeki $\left(\pi_{t}-\pi_{t}^{*}\right)$ terimi gerçekleşen enflasyon haddi ile hedeflenen enflasyon haddi arasındaki fark1 belirten enflasyon açığını göstermekte ve $(\alpha)$ terimi ise enflasyon açı̆̆ını kısa vadeli nominal faiz oranı ile ilişkilendiren enflasyon tepki katsayısını belirtmektedir. Enflasyonu temel hedefleri arasına alan para politikası uygulamalarında pozitif değerler alması beklenen $(\alpha)$ katsayısının değerinin artması/azalması para politikasının kısa vadeli nominal faiz oranı üzerinden enflasyona karşı duyarlılığının arttı̆̆ını/azaldığını belirtirken, $(\alpha)$ katsayısının değerinin sıfıra eşit olması ise para politikasının ve kısa vadeli nominal faiz oranının belirlenmesinde enflasyonun herhangi bir etkisinin bulunmadığını göstermektedir. Denklemdeki $\left(y_{t}-y_{t}^{*}\right)$ terimi gerçekleşen üretim düzeyi ile potansiyel üretim düzeyi arasındaki farkı belirten üretim açığını göstermekte ve $(\beta)$ terimi ise üretimi kısa vadeli nominal faiz oranı ile ilişkilendiren üretim tepki katsayısını belirtmektedir. Üretimi temel hedefleri arasına alan para politikası uygulamalarında pozitif değerler alması beklenen $(\beta)$ katsayısının değerinin artmas1/azalması para politikasının kısa vadeli nominal faiz oranı üzerinden üretime karşı duyarlılığının arttığını/azaldığını belirtirken, $(\beta)$ katsayısının değerinin sıfıra eşit olması ise para politikasının ve kısa vadeli nominal faiz 
oranının belirlenmesinde üretimin herhangi bir etkisinin bulunmadı̆̆ını göstermektedir (Clarida vd., 1998: 1037-38; Ball, 1999: 128-134).

Eşitlik 1'deki denkleme ilişkin açıklamalar dikkate alındığında orijinal Taylor kuralına göre, gerçekleşen enflasyon haddinin hedeflenen enflasyon haddine eşit olması (enflasyon açığının sıfıra eşit olması) ve gerçekleşen üretim düzeyinin potansiyel üretim düzeyine eşit olması (üretim açığının sıfıra eşit olması) durumunda kısa vadeli nominal faiz oranı $\left(i_{t}\right)$, denge reel faiz oranı $\left(r_{t}\right)$ ile gerçekleşen enflasyon haddinin $\left(\pi_{t}\right)$ toplamindan oluşmaktadır. Enflasyon ile üretim açığının ve dolayısıyla konjonktürel dalgalanmaların olmadığı böylesi bir makroekonomik ortamda, merkez bankaları tarafından politika faiz oranlarının değiştirilmesine yönelik bir para politikası uygulanmasının gerekliliği ortadan kalkmaktadır. Bu durumun dışındaki diğer makroekonomik ortamlarda ise orijinal Taylor kuralın işleyişi, enflasyon ile üretim açığının alacağı değerlere bağlı olmakta ve ilgili açıkların pozitif/negatif olması durumunda merkez bankaları tarafindan politika faiz oranlarının enflasyon ve üretim açığıyla aynı yönde değiştirilerek denge reel faiz oranının üzerinde/altında belirlenmesini gerekmektedir (Akat, 2004: 69).

Bununla birlikte, Eşitlik 1'deki denkleme döviz kurunun dâhil edilmemesi Taylor (1993) tarafından geliştirilen orijinal Taylor kuralının dışa açık ekonomiler açısından geçerliliğinin sorgulanmasına ve süreç içerisinde kurala dayalı bir para politikası uygulaması olarak etkinliğin tartışılmasına neden olmaktadır. Nitekim dışa açık ekonomilerde enflasyon hedeflemesi rejimini benimsemiş olan merkez bankalarının fiyat istikrarını sağlayıp sürdürülebilmeleri, finansal istikrarın önemli bir bileşeni olarak görülen döviz kurlarındaki değişimlerle yakından ilişkili olmaktadır (Clarida vd., 1998: 1036-1042; Greiber ve Herz, 2000: 9-10). Bu nedenlerle, dişa açık ekonomilerde orijinal Taylor kuralının para politikası uygulaması olarak etkinliğini artırabilmek üzere John B. Taylor (2001) tarafından Eşitlik 1'deki orijinal Taylor kuralı denklemi döviz kurlarının etkilerini içerecek bir şekilde genişletilerek yeniden tanımlanmaktadır. John B. Taylor (2001) tanımladığ1 bu yeni denklemle, merkez bankalarının kısa vadeli faiz oranlarını enflasyonun hedeflenen enflasyondan, üretimin ve döviz kurunun potansiyel düzeyinden sapmasına göre belirlemesini ve olası bir sapma karşısında kısa vadeli faiz oranlarını değiştirerek para piyasasına müdahale etmesi gerektiğini göstermektedir (Taylor, 2001: 264-65). Kısa vadeli faiz oranının; reel faiz oranının, enflasyon haddinin, enflasyon, üretim ve döviz kuru açığının bir fonksiyonu olduğunu belirten genişletilmiş Taylor kuralı denklemi Eşitlik 2'de gösterilmektedir:

$$
\mathrm{i}_{\mathrm{t}}=\mathrm{r}+\pi_{\mathrm{t}}+\alpha\left(\pi_{\mathrm{t}}-\pi_{\mathrm{t}}^{*}\right)+\beta\left(\mathrm{y}_{\mathrm{t}}-\mathrm{y}_{\mathrm{t}}^{*}\right)+\sigma\left(\mathrm{e}_{\mathrm{t}}-\mathrm{e}_{\mathrm{t}}^{*}\right)
$$


Burada Eşitlik 1'deki denkleme ilişkin açıklamalar geçerliyken $\left(e_{t}\right)$ ve $\left(e_{t}^{*}\right)$ terimleri sırasıyla $t$ dönemindeki gerçekleşen ve denge (potansiyel) nominal döviz kurunu belirtmektedir. Denklemdeki $\left(e_{t}-e_{t}^{*}\right)$ terimi, gerçekleşen döviz kuru ile potansiyel döviz kuru arasindaki farkı belirten döviz kuru açığını göstermekte ve $(\sigma)$ terimi ise döviz kuru açığını kısa vadeli nominal faiz oranı ile ilişkilendiren döviz kuru tepki katsayısını göstermektedir (Ball, 1999: 128-134; Greiber ve Herz, 2000: 9-10). Fiyat istikrarını sağlayabilmek üzere enflasyonun yanında finansal istikrarı da temel hedefleri arasina alan para politikası uygulamalarında pozitif değerler alması beklenen $(\sigma)$ katsayısının değerinin artması/azalması para politikasının kısa vadeli nominal faiz oranı üzerinden döviz kuruna karşı duyarlılığının arttığını/azaldığını belirtirken, $(\sigma)$ katsayısının değerinin sıfira eşit olması ise para politikasının ve kısa vadeli nominal faiz oranının belirlenmesinde döviz kurunun herhangi bir etkisinin bulunmadığını göstermektedir. (Bununla birlikte, $(\sigma)$ katsayısının alacağı değerler $(\alpha)$ ve $(\beta)$ katsayllarında olduğu gibi merkez bankalarının normatif düzenlemelerine gereksinim olmadan döviz kurları ile enflasyon arasındaki mevcut nesnel ilişkilerden hareketle belirlenebilmektedir). (Akat, 2004: 9-11). Eşitlik 2'deki genişletilmiş Taylor kuralına göre, enflasyon açı̆̆ının, üretim açı̆̆ının ve döviz kuru açığının sıfıra eşit olması durumunda kısa vadeli nominal faiz oranı $\left(i_{t}\right)$, denge reel faiz oranı $\left(r_{t}\right)$ ile gerçekleşen enflasyon haddinin $\left(\pi_{t}\right)$ toplamına eşit olmaktadır. Enflasyon, üretim ve döviz kuru açı̆̆ının olmadığı böylesi bir makroekonomik ortamda, merkez bankaları tarafindan politika faiz oranlarının değiştirilmesine yönelik bir para politikası uygulanmasının gerekliliği ortadan kalkmaktadır. $\mathrm{Bu}$ durumun dışındaki diğer makroekonomik ortamlarda ise genişletilmiş Taylor kuralın işleyişi, enflasyon, üretim ve döviz kuru açı̆̆ının alacağı değerlere bağlı olmakta ve ilgili açıkların pozitif/negatif olması durumunda merkez bankaları tarafindan politika faiz oranlarının ilgili açıklarla aynı yönde değiştirilerek denge reel faiz oranının üzerinde/altında belirlenmesini gerekmektedir.

Taylor (1993-2001) tarafindan kurala dayalı bir para politikası uygulamas1 olarak geliştirilen ve para piyasası politika faiz oranının; enflasyon haddi, üretim düzeyi ve döviz kuru açıklarının bir fonksiyonu olduğunu belirten teorik düzeydeki çalışmalarının ardından oluşmaya başlayan literatür incelendiğinde, orijinal ve genişletilmiş Taylor kuralının geçerliliğinin gelişmiş ve gelişmekte olan farklı ülkeler üzerinde araştırma konusu yapıldığı görülmektedir. Bununla birlikte, Taylor kuralının geçerliliğini ampirik açıdan araştıran bu çalışmaların bir bölümünde faiz ile enflasyon, üretim ve döviz kuru açığ1 değişkenlerinin cari dönem değerleri kullanılarak orijinal ve genişletilmiş Taylor kuralının geçerliliği araştırlırken, bir bölümünde ise faiz ile enflasyon, üretim ve döviz kuru açığı değişkenlerinin geçmiş veya gelecek dönem değerleri kullanılarak orijinal ve genişletilmiş Taylor kuralının geriye veya ileriye dönük varyasyonlarının geçerliliği incelenmektedir (Darıcı, 2010: 
41-54). Para piyasası politika faiz oranının temel para politikası aracı olarak kullanıldığ1 bu kurallar Taylor (1993-2001) çalışmalarının ardından Taylor tipi kurallar olarak adlandırılmakta ve orijinal, genişletilmiş, geriye dönük ve ileriye dönük Taylor kurallarının oluşmasında, faiz ile enflasyon, üretim ve döviz kuru açığı değişkenlerinin zamanlaması, ölçümlenmesi vb. konulardaki farklılıklar belirleyici olmaktadır (Çağlayan ve Astar, 2011: 75).

İlgili literatürde, Taylor tipi kuralların gelişmiş ve gelişmekte olan farklı ülkelerdeki geçerliliğini konu edinen ve genellikle zaman serisi analizi kapsamında yapılan bu kapsamdaki ampirik çalışmalarda, orijinal ve genişletilmiş Taylor kuralları ile bu kuralların geriye dönük ve ileriye dönük varyasyonlarının geçerliliği Sıradan En Küçük Kareler-OLS, Dinamik En Küçük Kareler-DOLS, Genelleştirilmiş Momentler Metodu-GMM, Vektör Otoregresif Model-VAR, Gecikmesi Dağıtılmış Otoregresif Model-ARDL, Doğrusal Olasılıklı Logit ve Probit Modelleri vb. şeklindeki doğrusal ve doğrusal olmayan tahminciler kullanılarak araştırılmaktadır. Bu kapsamdaki çalışmaların ağırlıklı bir bölümünde orijinal ve genişletilmiş Taylor kuralı ile orijinal ve genişletilmiş Taylor kuralının geriye ve ileriye dönük varyasyonlarının kapsanan ülkelerde, enflasyon, üretim ve döviz kuru açı̆̆ı açısından geçerli olduğu belirlenmektedir. Bu yönüyle bu çalışmalarda, para piyasası politika faiz oranlarının; enflasyon, üretim ve/veya döviz kuru açığı değişkenlerinin, cari, geçmiş veya gelecek dönem değerlerindeki değişimlere karşı farklı derecelerde duyarlı olduğu sonucuna ulaşılmaktadır. ((Taylor 1993; Amerika Birleşik Devletleri-ABD), (Kamin ve Rogers 1996; Meksika), (Judd ve Rudebusch 1998; ABD), (Clarida vd., 1998; ABD, Almanya, Japonya, İngiltere, Fransa, İtalya), (Kesriyeli ve Yalçın 1998; Türkiye), (Taylor 1998; ABD), (Ball 1999; Yeni Zelanda), (Kozicki 1999; ABD), (Nelson 2000; İngiltere), (Gerlach ve Schabel 2000; Avusturalya, Belçika, Finlandiya, Fransa, Almanya, İlanda, İtalya, Hollanda, Portekiz, Fransa, Lüksemburg, İspanya), (Chevapatrakul vd., 2002; İngiltere), (Bec vd., 2002; ABD, Fransa, Almanya), (Gerdesmeier ve Roffia 2004; Almanya), (Dolores vd., 2004; ABD), (Dolares 2005; Çek Cumhuriyeti, Polonya, Macaristan, Slovakya), (Yazgan ve Yilmazkuday 2007; Türkiye, İsrail), (Aklan ve Nargeleçekenler 2008; Türkiye), (Bunzel ve Enders 2010; ABD), (Orlowski 2010; Çek Cumhuriyeti, Polonya, Macaristan), (Çağlayan ve Astar 2011; Türkiye), (Demirbaş ve Kaya 2012; Türkiye), (Markov ve Nitschka 2013; İsviçre), (Ardor ve Varlık 2014; Türkiye), Albayrak ve Abdioğlu 2015; Türkiye), (Wang vd., 2016; ABD, Avusturalya İsveç, İngiltere), (Gögül ve Songur 2016; Türkiye), (Chen vd., 2017; ABD, Çin, Japonya, İngiltere), (Conraria vd., 2018; ABD), (Boehm ve House 2019; ABD)).

Bu kapsamdaki çalışmaların sınırlı bir bölümünde ise orijinal ve genişletilmiş Taylor kuralı ile orijinal ve genişletilmiş Taylor kuralının geriye ve ileriye dönük varyasyonlarının kapsanan ülkelerde enflasyon açı̆̆ı açısından geçerli olduğu ve/fakat üretim ve/veya döviz kuru açığı açısından 
geçerli olmadığı belirlenmektedir. Bu yönüyle bu çalışmalarda, para piyasası politika faiz oranlarının; enflasyon açığı değişkeninin cari, geçmiş veya gelecek dönem değerlerindeki değişimlere farklı derecelerde duyarlı olduğu, ancak üretim ve/veya döviz kuru açığı değişkeninin cari, geçmiş veya gelecek dönem değerlerindeki değişimlere karşı duyarsız olduğu sonucuna ulaşılmaktadır. ((Mehra 1994; ABD), (Gascoigne ve Turner 2004; İngiltere), (Österholm 2005; ABD, Avusturya, İsveç), (Dolares 2005; Slovakya), (Leiderman vd., 2006; Şili, Kolombiya, Peru, Bolivya), (Shibamoto 2008; Japonya), (Vasicek 2009; Bulgaristan, Güney Kıbris, Çek Cumhuriyeti, Estonya, Macaristan, Malta, Letonya, Litvanya, Polonya, Romanya, Slovakya, Slovenya), (Bal vd., 2016; Türkiye), (Caporale vd., (2018; Endonezya, Güney Kore, İsrail, Tayland, Türkiye)).

Orijinal ve genişletilmiş Taylor kurallarının geçerliliğini ampirik açıdan araştıran literatür bir bütün olarak değerlendirildiğinde, Taylor (1993-2001) çalışmalarının ardından oluşmaya başlayan literatürün 2000'li yıllardan itibaren önemli bir gelissim gösterdiği görülmektedir. Bununla birlikte, orijinal ve genişletilmiş Taylor kurallarının geçerliliğini ampirik açıdan araştıran öncü çalışmalarda genellikle ABD ve İngiltere gibi gelişmiş ülkelerin kapsandığı ve gelişmekte olan ülkelerdeki ampirik geçerliliğinin konu edinilmesinin ise son yıllarda önem kazandığı izlenmektedir. Literatürdeki gelişimle birlikte zamanla geriye dönük ve ileriye dönük varyasyonları da geliştirilen Taylor tipi kuralların geçerliliğini konu edinen çalşsmalar, gelişmiş ve gelişmekte olan farklı ülkeler üzerine ve genellikle zaman serisi analizi kapsamında yapılmaktadır. Bu kapsamda, Taylor tipi kuralların gelişmiş ve gelişmekte olan ülkelerdeki ampirik geçerliliğini araştıran çalışmalarda genel bir sonuca varılamadığı ve Taylor tipi kuralların genellikle enflasyon ve üretim açığı açısından geçerli olduğu belirlenirken, döviz kuru açığı açısından ise geçerli olmadığı tespit edilmektedir. Türkiye üzerine yürütülen çalısmalar açısından da geçerli olan bu durum para piyasası politika faiz oranlarının; enflasyon, üretim ve/veya döviz kuru açığındaki değişimlere farklı derecelerde duyarlı olduğunu ve Taylor tipi kuralların geçerliliğinin; çalışmalarda kullanılan ekonometrik metodoloji ile tahmincilere, Taylor kuralının varyasyonuna, örneklem dönemine, veri setine vb., göre değişme eğiliminde olduğunu göstermektedir.

$\mathrm{Bu}$ çalışmada ise orijinal ve genişletilmiş Taylor kurallarının TCMB açısından geçerliliği doğrusal ve doğrusal olmayan zaman serisi analizi kapsamında 2002:Q1-2019Q:2 dönemi için ampirik olarak incelenmektedir. Gelişmekte olan bir ülke konumundaki Türkiye ekonomisi özelinde 2002 yllından bu yana enflasyon hedeflemesi rejimini benimsemiş olan TCMB üzerine yürütülen çalışmanın bulgularının, bu konudaki ampirik literatürün gelişimine kullanılan Taylor kuralı varyasyonları, örneklem dönemi ve doğrusal ve doğrusal olmayan ekonometrik yöntemler itibariyle katkı sağlayacağı değerlendirilmektedir. 


\section{Araştırmanın Verileri, Ekonometrik Metodolojisi ve Bulguları}

\subsection{Araştırmanın Verileri}

Çalışmanın bu bölümünde, orijinal ve genişletilmiş Taylor kurallarının TCMB açısından 2002:Q1-2019Q:2 dönemindeki geçerliliğini belirlemek üzere ekonometrik analizlerde kullanılan değişkenler tanıtılmakta ve değişkenlere ait verilerin dönüştürülme işlemleri açıklanmaktadır. Bu amaçla, TCMB açısından orijinal ve genişletilmiş Taylor kurallarının geçerliliğini sırasıyla Eşitlik 1 ve 2'de tanımlanan denklemlere dayalı olarak belirlemek üzere çalışmanın ekonometrik analizlerinde 2002:Q1-2019Q:2 dönemi için çeyreklik bazda kullanılan değişenler ile kaynakları Tablo 1'de sunulmaktadır. (Çalışmanın örneklem döneminin 2002Q:1-2019Q:2 olarak belirlenmesinde, kurala dayalı para politikası uygulamaları olarak orijinal ve genişletilmiş Taylor kurallarının enflasyon hedeflemesi rejiminin uygulama özelliklerine uyumlu olmasi ve TCMB tarafindan enflasyon hedeflemesi rejiminin 2002 yılından itibaren benimsenmiş olması etkili olmaktadır. Bununla birlikte çalışmanın, 2002-2019 dönemine ait çeyreklik verileri kapsamasında, orijinal ve genişletilmiş Taylor kuralı denklemlerindeki üretim açığı değişkeninin oluşturulmasında kullanılan Gayri Safi Yurtiçi Hâsıla-GSYH verilerinin çeyreklik bazda hesaplanması belirleyici olmaktadır).

Tablo 1: Analizlerde Kullanılan Değişkenlerin Tanımlanması

\begin{tabular}{|c|c|c|}
\hline $\begin{array}{c}\text { Değişkenlerin } \\
\text { Kısaltması }\end{array}$ & Değişkenlerin Tanımı & Değişkenlerin Veri Kaynakları \\
\hline FO & $\begin{array}{l}\text { Para Piyasası Politika } \\
\text { Faiz Oranı } \\
\text { (Gecelik Borç Verme } \\
\text { Faiz Oranı) }\end{array}$ & \multirow{4}{*}{$\begin{array}{l}\text { TCMB-EVDS, (Türkiye Cumhuriyet } \\
\text { Merkez Bankasi-Elektronik Veri } \\
\text { Dağıtım Sistemi-2019). } \\
\text { (Yazarların Hesaplamaları). }\end{array}$} \\
\hline EA & Enflasyon Açı̆̆ı (TÜFE) & \\
\hline YA & $\begin{array}{c}\text { Üretim Açı̆ (Reel } \\
\text { GSYH). }\end{array}$ & \\
\hline DA & $\begin{array}{c}\text { Döviz Kuru Açı̆ı } \\
\text { (Nominal Döviz Kuru } \\
\text { (USD) }\end{array}$ & \\
\hline
\end{tabular}

Tablo 1'de tanımlanan ve EVDS veri tabanından alınan Gecelik Borç Verme Faiz Oran1, Tüketici Fiyat Endeksi-TÜFE, Reel Gayri Safi Yurtiçi Hâsıla-GSYH ve Nominal Döviz Kuru (ABD Doları-USD) ham verilerinin kullanılmasıyla oluşturulan FO, EA, YA ve DA değisskenlerinin ekonometrik analizlerde kullanılan formlarına dönüştürülmesinde yazarlar tarafindan izlenilen yöntemler şu şekilde açıklanabilmektedir: Bu kapsamda, FO, EA, YA ve DA değişkenlerinin türetilmesinde kullanılan ve EVDS veri tabanından alınan ilgili ham verilerinin, öncelikle inceleme dönemindeki doğal logaritmaları alınmakta ve ardından doğal logaritmik formdaki veriler 
EViews 10.0 ekonometri paket programinda Census X-13 metodu ile mevsimsellikten arındırılmaktadır. Böylelikle faklı türlerde hesaplanan verilerin benzer büyüklükte ölçümlenmesi, inceleme dönemindeki mevsimsel özelliklerinden arındırılması ve ekonometrik analizlerde kullanılan FO, EA, YA ve DA değişkenleri arasındaki ilişkilerin daha tutarlı bir şekilde incelenebilmesi amaçlanmaktadır.

Tablo 1'deki para piyasası politika faiz oranı FO değişkenine ait veriler, EVD veri tabanından TCMB'nin para politikasının operasyonel işlemlerinde kullandığ1 Gecelik Borç Verme Faiz Oranı (\%) olarak alınmaktadır. Enflasyon Açığı-EA, Üretim Açı̆̆1-YA ve Döviz Kuru Açı̆̆ı-DA değişkenleri, sırasıyla EVDS veri tabanından 2002:Q1-2019:Q2 dönemi için alınan baz yll $(2003=100)$ olarak hesaplanan Tüketici Fiyat Endeksi-TÜFE, zincir hacim yöntemiyle hesaplanan Reel Gayri Safi Yurtiçi Hâsila-GSYH ve ABD dolarının alış-satış kurlarının ortalama dönemlik değerleri üzerinden hesaplanan Nominal Döviz Kuru (USD) verilerinin kullanılmasıyla türetilmektedir. EA, YA ve DA değişkenleri türetilirken, öncelikle 2002:Q12019:Q2 dönemi için doğal logaritması alınan ve mevsimsellikten arındırılan TÜFE, GSYH ve Nominal Döviz Kuru verileri, Hodrick-Prescott Filtrelemesinden (HPF) geçirilmekte ve TÜFE, GSYH ve Nominal Döviz Kuru verilerinin örneklem dönemindeki potansiyel değerleri hesaplanmaktadır. Hodrick-Prescott (1997) tarafından geliştirilerek zaman serilerinin trend ve devresel hareketlerini en aza indirecek bir şekilde bileşenlerine ayrıştırılabilmesine olanak sağlayan HPF, zaman serilerinin gerçekleşen gözlem değerleri üzerinden potansiyel değerlerinin hesaplanmasinda ampirik literatürde en fazla kullanılan filtreleme yöntemleri arasinda bulunmaktadir. (Hodrick ve Prescott, 1997:1-16; Alp vd., 2011:1). (TÜFE, GSYH ve Nominal Döviz Kuru verilerinin HPF işlemi EViews 10.0 ekonometri paket programı kullanılarak yapılmaktadır). HPF işleminin ardından TÜFE, GSYH ve Nominal Döviz Kuru verilerinin 2002:Q12019:Q2 dönemindeki gerçekleşen değerlerinden potansiyel değerlerinin çıkarılmasıyla ekonometrik analizlerde kullanılan Enflasyon Açığı-EA, Üretim Açığı-YA ve Döviz Kuru Açığı-DA değişkenleri elde edilmektedir. Bununla birlikte, EA, YA ve DA değişkenleri türetilirken potansiyel verilerin HPF işlemi kullanılarak elde edilmesinde, EA, YA ve DA değişkenlerinin HPF işlemiyle uyumlu bir şekilde hesaplanabilmesi ve ekonometrik analizlerde kullanılan FO, EA, YA ve DA değişkenleri arasındaki ilişkilerin daha tutarlı bir şekilde incelenebilmesi amacı etkin olmaktadır.

Tüm bu veri dönüştürme işlemlerinin ardından FO, EA, YA ve DA değişkenlerinin ekonometrik analizlerde kullanılacak formlarının 2002Q:12019Q:2 dönemindeki zaman serisi özelliklerine ait tanımlayıc istatistikler ise Tablo 2'de sunulmaktadır. 
Taylor Kurah Kapsamında Türkiye Cumhuriyet Merkez Bankası Pa...

Tablo 2: Değişkenlere Ait Tanımlayıcı İstatistikler

\begin{tabular}{c|c|c|c|c|c|c|}
\hline Değişkenler & Ortalama & Medyan & $\begin{array}{c}\text { Standart } \\
\text { Sapma }\end{array}$ & Minimum & Maksimum & Gözlem \\
\hline FO & 2.459 & 2.594 & 0.883 & 0.414 & 4.448 & 70 \\
\hline EA & 0.007 & -0.003 & 0.046 & -0.051 & 0.144 & 70 \\
\hline YA & -0.002 & 0.004 & 0.047 & -0.253 & 0.094 & 70 \\
\hline DA & 0.015 & -0.003 & 0.105 & -0.162 & 0.346 & 70 \\
\hline
\end{tabular}

Tablo 2 incelendiğinde, FO ve $\mathrm{DA}$ değişkenlerinin örneklem döneminde ortalama, medyan, minimum, maksimum ve standart sapma istatistikleri açısından aldıkları değerlerin EA ve YA değişkenlerine kıyasla daha yüksek olduğu görülmektedir. $\mathrm{Bu}$ durum, örneklem döneminde para piyasas1 politika faiz oranları ile döviz kurlarında meydana gelen değişimlerin, enflasyon ve üretimde meydana gelen değissimlerden daha fazla olduğunu göstermektedir.

\subsection{Araştırmanın Ekonometrik Metodolojisi ve Bulguları}

Çalışmanın bu bölümünde, TCMB tarafindan para piyasası politika faiz oranlarının belirlenmesinde kurala dayalı bir para politikası uygulaması olan Taylor kuralının geçerli olup olmadığının 2002:Q1-2019Q:2 dönemi için ampirik olarak incelenmesi amaçlanmaktadır. Bu amaçla çalışmada, dışa kapalı ve dışa açık ekonomi varsayımlarına dayalı olarak geliştirilen orijinal ve genişletilmiş Taylor kurallarının TCMB açısından geçerliliğini belirlemek üzere Eşitlik 1 ve 2'de tanımlanan Taylor kuralı denklemleri kullanılarak 2002:Q1-2019Q:2 dönemi için ayr1 ayrı tahmin edilecek ekonometrik modeller aşağıdaki eşitliklerde gösterilmektedir: (Çalışmada tanımlanan modellerin ekonometrik analizlerinde EViews 10.0 ve WinRATS 9.1 paket programları kullanılmaktadır).

$$
\begin{aligned}
& \text { Model-1: } F O_{t}=\partial_{\mathrm{t}}+\alpha \mathrm{EA}_{\mathrm{t}}+\beta \mathrm{YA}_{\mathrm{t}}+\varepsilon_{\mathrm{t}} \\
& \text { Model-2: } F O_{t}=\partial_{\mathrm{t}}+\alpha \mathrm{EA}_{\mathrm{t}}+\beta \mathrm{YA}_{\mathrm{t}}+\sigma \mathrm{DA}_{\mathrm{t}}+\varepsilon_{\mathrm{t}}
\end{aligned}
$$

Eşitliklerde $\left(\partial_{\mathrm{t}}=r_{t}+\pi_{t}\right)$ göstermek üzere modellerdeki terimlerden; $(\partial),(\alpha),(\beta),(\sigma),(\varepsilon)$ ve $(\mathrm{t})$ sirasiyla sabit parametreyi, enflasyon, üretim ve döviz kuru açığı değişkenlerine ait eğim parametrelerini, hataları ve zamanı göstermektedir. Orijinal ve genişletilmiş Taylor kurallarının TCMB açısından 2002:Q1-2019Q:2 dönemindeki geçerliliğini belirlemek üzere Eşitlik 3 ve 4 'te tanımlanan modeller doğrusal ve doğrusal olmayan zaman serisi analizi metodolojisi kullanılarak ayrı ayrı tahmin edilmektedir.

Modeldeki değişkenlerin durağanlık koşulunun belirlenmesinin önemli olduğu zaman serisi analizlerinde durağan olmayan değişkenlerin kullanilmas1, sapmalı test istatistiklerine ve sahte regresyon olgusuna yol açabilmektedir. Bu nedenle, zaman serisi analizlerinde sapmasız test istatistik değerleri elde edebilmek ve sahte regresyon olgusundan kaçınabilmek üzere öncelikle modeldeki değişkenlerin durağanlık koşulunun tespit edilmesi 
gerekmektedir (Gujarati, 2009: 709-711). Zaman serisi analizlerinde modeldeki değişkenlerin durağanlık koşulu ise serilerin simetrik ve asimetrik özelliklerini, deterministik ve stokastik yapısını vb. dikkate alarak çeşitli varsayımlar altında test istatistikleri hesaplayabilen doğrusal ve doğrusal olmayan farklı nitelikteki birim kök testleriyle incelenebilmektedir. Nitekim zaman serisi analizlerinde modeldeki değişkenlerin inceleme dönemindeki hareketleri doğrusal veya doğrusal olmayan eğilimler gösterebilmekte ve bu eğilimleri dikkate almadan uygulanan birim kök testleri değişkenlerin durağanlığ1 konusunda sapmalı sonuçlar verebilmektedir (Cuestas ve Garrant, 2011: 557). Zaman serisi analizi kapsamındaki bu çalışmada anılan sakıncaları gidererek sapmasız sonuçlar elde edebilmek (sahte birim kökten kaçınabilmek) üzere modeldeki değişkenlerin durağanlık koşulu, doğrusal (Augmented Dickey-Fuller-ADF ile Phillips-Perron-PP) ve doğrusal olmayan (Kapetanios, Shin ve Snell-KSS ile Sollis-SLS) farklı nitelikteki birim kök testleriyle araştırılmaktadır.

Zaman serilerinin inceleme dönemindeki hareketlerinin doğrusal eğilimler göstermesi durumunda kullanilabilen Dickey ve Fuller (1976-1979) ve Phillips ve Perron (1988) tarafından geliştirilen ADF ve PP birim kök testleri, değişkenlerdeki otokorelasyonun giderilebilmesine yönelik çeşitli varsayımlar altında durağanlık analizi yapabilmektedir. ADF birim kök testinde, hata terimlerindeki otokorelasyonun bağımsız değişkenin gecikmeli değerlerinin model eklenmesiyle giderildiği varsayllmakta ve testin uygulanabilmesi için hata terimlerindeki otokorelasyonun doğru derecesinin belirlenmesi gerekmektedir. PP birim kök testinde ise ADF testindeki rassal şokların dağılımları ile ilgili olan bu varsayım geliştirilerek zaman serilerindeki yüksek derecedeki korelasyonu kontrol etmek için parametrik olmayan bir yöntemle durağanlık analizi yapılmaktadır. Bu yönüyle, ADF birim kök testinin tamamlayıcısı olan PP birim kök testinde otokorelasyonu gidermeye yetecek kadar bağımlı değişkenin gecikmeli değerleri ilave edilmemekte, onun yerine katsay1 Newey-West tahmincisi ile uyarlanmaktadır (Phillips ve Perron, 1988: 335-46). Bununla birlikte, doğrusal ADF ve PP birim kök testlerinde serilerin durağanllğı "seride birim kök bulunmaktadır" temel hipoteziyle araştırılmakta ve sabitli ve trendli formlarda hesaplanan test istatistiklerinin kritik tablo değerlerinden mutlak olarak büyük olması durumunda, temel hipotez reddedilmektedir.

Zaman serilerinin inceleme dönemindeki hareketlerinin doğrusal olmayan eğilimler göstermesi durumunda kullanılabilen Kapetanios, Shin ve Snell (2003) ve Sollis (2009) tarafindan geliştirilen KSS ve SLS birim kök testleri, değişkenlerin simetrik veya asimetrik özellikler göstermesine yönelik çeşitli varsayımlar altında durağanlık analizi yapabilmektedir. KSS birim kök testinde, asimetrik zaman serisinin üssel ve yumuşak geçişli bir otoregresif süreç izlediği varsayllırken, SLS birim kök testinde simetrik veya asimetrik zaman serisinin üssel veya lojistik yumuşak geçişli bir otoregresif süreç 
izlediği kabul edilmektedir. KSS birim kök testinde, $(\theta)$ geçiş hızını belirleyen parametreyi göstermek üzere durağanlık analizi, $(\theta=0)$ etrafinda birinci mertebeden Taylor açılımını kullanan aşağıdaki yardımcı regresyon denklemine dayalı olarak yapılmaktadır:

$$
\Delta y_{t}=\delta y_{t-1}^{3}+\varepsilon_{t}
$$

Burada $\left(y_{t-1}^{3}\right)$ değişkeni ESTAR (Exponential Smooth Transition Autoregressive-Üstsel Yumuşak Geçişli Otoregresif) doğrusal olmama durumunu gösterirken, denklem en küçük kareler yöntemiyle zaman serisinin ortalamadan ve trendden arındırılmış şekline göre tahmin edilmekte ve doğrusal olmayan $\mathrm{t}$ test istatistiği $\left(t_{N L}=\hat{\delta} / s_{\widehat{\delta}}\right)$ formülüyle hesaplanmaktadir. KSS birim kök testinde, $(\delta=0)$ temel hipotezi $(\delta<0)$ alternatif hipotezine karşı sinanmakta ve $\left(t_{N L}\right)$ test istatistiğinin simülasyonlarla elde edilen KSS kritik tablo değerlerinden mutlak olarak küçük olması durumunda "seride birim kök bulunmaktadır" temel hipotezi reddedilememektedir (Kapetanios et al., 2003:359-379). SLS birim kök testinde ise $(\theta)$ geçiş hızını belirleyen parametreyi göstermek üzere durağanlık analizi, $\left(\theta_{1}=0\right)$ etrafında birinci mertebeden Taylor açlımını kullanan aşağıdaki yardımcı regresyon denklemine dayalı olarak yapilmaktadir:

$$
\Delta y_{t}=\delta_{1} y_{t-1}^{3}+\delta_{2} y_{t-1}^{4}+\varepsilon_{t}
$$

Eşitlikteki $\left(y_{t-1}^{3}\right)$ değişkeni simetrik ve $\left(y_{t-1}^{4}\right)$ değişkeni ise asimetrik ESTAR doğrusal olmama durumunu gösterirken, denklem en küçük kareler yöntemiyle zaman serisinin ortalamadan ve trendden arındirılmış şekline göre tahmin edilmekte ve doğrusal olmayan $\mathrm{F}$ test istatistikleri hesaplanmaktadir. SLS birim kök testinde, $\left(\delta_{1}=\delta_{2}=0\right)$ temel hipotezi $\left(\delta_{1} \neq \delta_{2} \neq 0\right)$ alternatif hipotezine karşı sinanmakta ve $\mathrm{F}$ test istatistiğinin simülasyonlarla elde edilen SLS kritik tablo değerlerinden küçük olması durumunda "seride birim kök bulunmaktadı" temel hipotezi reddedilememektedir (Sollis, 2009:118-125).

Tanımlanan modellerdeki değişkenlerin durağanlık durumunu sabitli ve trendli ile ortalamadan ve trendden arındırılmış formlarda araştıran doğrusal (ADF ve PP) ve doğrusal olmayan (KSS ve SLS) birim kök testleri sonuçları Tablo 3'te sunulmaktadir.

Tablo 3: Doğrusal ve Doğrusal Olmayan Birim Kök Testleri Sonuçları

\begin{tabular}{c|c|c|c|c|c|c|c|}
\hline Test İstatistikleri & \multicolumn{3}{|c|}{ ADF } & \multicolumn{3}{c|}{ PP } & \multirow{2}{*}{ I } \\
\cline { 1 - 9 } Değişkenler & LV & FD & L & LV & FD & L & \\
\hline FO & -1.89 & $-6.86^{\mathrm{a}}$ & 1 & -1.25 & $-7.38^{\mathrm{a}}$ & 8 & I(1) \\
\hline EA & -2.11 & $-8.45^{\mathrm{a}}$ & 1 & -3.00 & $-8.98^{\mathrm{a}}$ & 5 & I(1) \\
\hline YA & -1.39 & $-5.69^{\mathrm{a}}$ & 0 & -1.65 & $-6.28^{\mathrm{a}}$ & 2 & I(1) \\
\hline DA & $-4.33^{\mathrm{b}}$ & - & 5 & $-3.52^{\mathrm{b}}$ & - & 3 & I(0) \\
\hline
\end{tabular}




\begin{tabular}{|c|c|c|c|c|c|c|c|c|}
\hline \multirow{2}{*}{ Kritik Tablo Değerleri } & $\% 1$ & \multicolumn{3}{|c|}{-4.09} & \multicolumn{3}{|c|}{-4.09} & \\
\hline & $\% 5$ & \multicolumn{3}{|c|}{-3.47} & \multicolumn{3}{|c|}{-3.47} & \\
\hline \multicolumn{2}{|l|}{ Test İstatistikleri } & \multicolumn{3}{|c|}{ KSS } & \multicolumn{3}{|c|}{ SLS } & \\
\hline \multicolumn{2}{|l|}{ Değişkenler } & LV & FD & $\mathbf{L}$ & $\mathbf{L V}$ & FD & $\mathbf{L}$ & 1 \\
\hline \multicolumn{2}{|l|}{ FO } & -2.03 & $-3.62^{b}$ & 3 & 5.62 & $13.80^{\mathrm{a}}$ & 1 & $\mathrm{I}(1)$ \\
\hline \multicolumn{2}{|l|}{ EA } & -3.21 & $-6.42^{\mathrm{b}}$ & 2 & 5.09 & $23.62^{\mathrm{a}}$ & 2 & $\mathrm{I}(1)$ \\
\hline \multicolumn{2}{|l|}{ YA } & -2.65 & $-3.63^{b}$ & 2 & 3.50 & $8.47^{\mathrm{b}}$ & 2 & $\mathrm{I}(1)$ \\
\hline \multicolumn{2}{|l|}{ DA } & $-3.89^{\mathrm{b}}$ & - & 1 & $7.91^{\mathrm{b}}$ & - & 3 & \multirow[t]{3}{*}{$\mathrm{I}(0)$} \\
\hline \multirow{2}{*}{ Kritik Tablo Değerleri } & $\% 1$ & \multicolumn{3}{|c|}{-3.93} & \multicolumn{3}{|c|}{8.53} & \\
\hline & $\% 5$ & \multicolumn{3}{|c|}{-3.40} & \multicolumn{3}{|c|}{6.46} & \\
\hline
\end{tabular}

Not: Test istatistiklerinin önündeki " $a$ " ve "b" simgeleri, değişkenlerin sırasılyla \% 1 ve \% 5 önem düzeyinde durağan olduğunu göstermektedir. Tablodaki "L" sütunu ADF, KSS, SLS ile PP testlerinde Schwarz Bilgi Kriterinin (SIC) ve Bartlett Kernel metodunun kullanımıla belirlenen optimal gecikme uzunluklarını belirtmektedir. Kritik tablo değerleri ADF ve PP testleri için MacKinnon (1996) tarafindan geliştirilen değerleri gösterirken, KSS ve SLS testleri için sırasıyla Kapetanios vd., (2003) ve Sollis (2009) çalışmalarından alınan değerleri belirtmektedir.

Tablo 3'teki sonuçlar incelendiğinde, ADF, PP, KSS ve SLS birim kök testlerine göre $\% \quad 1$ veya $\% \quad 5$ önem düzeyinde modellerdeki DA değişkeninin seviye değerinde durağan olduğu (LV), FO, EA ve YA değişkenlerinin ise birinci farklarında (FD) durağanlaştıkları görülmektedir. Bu durum, \% 1 veya $\% 5$ önem düzeyinde $\mathrm{FO}, \mathrm{EA}$, YA ile DA şeklindeki model değişkenleri için FD ile LV düzeylerinde hesaplanan ADF, PP, KSS ve SLS birim kök testi istatistiklerinin kritik tablo değerlerinden mutlak olarak büyük veya küçük olmasından anlaşılabilmektedir. Hem doğrusal hem de doğrusal olmayan birim kök testlerinden elde edilen bu sonuçlar, DA şeklindeki model değişkeninin seviye düzeyinde $[\mathrm{I}(0)]$, FO, EA, YA DA şeklindeki model değisskenlerinin ise birinci farklarında [I(1)] durağanlaştıklarını ve modelin farklı derecelerden bütünleşik değişkenlerden oluştuğunu göstermektedir. Bu durum, zaman serisi analizlerinde farklı derecelerde ve en fazla [I(1)] düzeyinde bütünleşik olduğu belirlenen model değişkenleri arasındaki uzun dönemde olması muhtemel eş-bütünleşik ilişkilerin, ARDL (Autoregressive Distributed Lag-Gecikmesi Dağıtılmış Otoregresif) modeliyle belirlenmesini gerektirmektedir. Bununla birlikte, zaman serisi analizlerinde farklı derecelerden bütünleşik değişkenlerden oluşan doğrusal ve doğrusal olmayan modellerde, değişkenler arasındaki uzun dönemli eş-bütünleşik ilişkiler sırasıyla Doğrusal-Linear (L-ARDL) ve Doğrusal Olmayan-Nonlinear (NL-ARDL) modelleriyle araştırlabilmektedir.

Pesaran et al., (2001) tarafindan geliştirilen L-ARDL modeli, farklı derecelerden $I(0)$ veya $I(1)$ bütünleşik olan değişkenler asındaki uzun dönemli ilişkilerin simetrik yönünün incelenmesine olanak tanımaktadır. Model tahminlerinde bağımlı ve açıklayıcı değişkenlerin gecikmeli değerleri kullanıldığından gecikmesi dağıtılmış otoregresif model olarak da 
adlandırılan L-ARDL modelinin, otokorelasyon ve içsellikten kaynaklı problemleri giderilebildiği ve küçük örneklemlerde dahi tutarlı sonuçlar verebildiği varsayılmaktadır. Kısıtsız Hata Düzeltme Modeline (Unrestricted Error Correction Model-UECM) dayanan L-ARDL $(p, q)$ modelinde, $\left(y_{t}\right)$ ve $\left(x_{t}\right)$ gibi iki zaman serisi değişkeni arasındaki kısa ve uzun dönemli simetrik ilişkiler aşağıdaki temel regresyon denklemi üzenden araştırılabilmektedir:

$y_{t}=\sum_{i=1}^{p} \lambda_{i} y_{t-j}+\sum_{i=0}^{q} \delta_{i}^{* \prime} x_{t-i}+\varepsilon_{t}$

Burada; $\left(y_{t}\right)$ bağımlı değişkeni ve $\left(x_{t}\right),(k \times 1)$ boyutlu dışsal değişkenler vektörünü gösterirken, $(p, q)$ sirasıyla $\left(y_{t}\right)$ ve $\left(x_{t}\right)$ değişkenlerinin dağıtılmış gecikmeli değerlerini belirtmektedir. Eşitlikteki $\left(\delta_{i}^{* \prime}\right)$ dişsal değişkenlerin $(k \times 1)$ boyutlu katsayılar vektörünü, $\left(\lambda_{i}\right)$ skaler vektörünü ve $\left(\varepsilon_{t}\right)$ sıfır ortalamaya ve sonlu varyansa sahip olan hata terimini göstermektedir. Eşitlik 7'deki denklem simetrik ve UECM formatında aşağıdaki gibi yaz1labilmektedir:

$\Delta y=\phi y_{t-1}+\beta_{i}^{\prime} x_{t}+\sum_{i=1}^{p-1} \lambda_{i}^{*} \Delta y_{t-i}+\sum_{i=0}^{q-1} \delta_{i}^{* \prime} \Delta x_{t-i}+\varepsilon_{t}$

Burada; $\phi=-1\left(1-\sum_{j=1}^{p} \lambda_{j}\right) ; \beta_{i}=\sum_{i=0}^{q} \delta_{i}, \quad \lambda_{i}^{*}=\sum_{m=i+1}^{p} \lambda_{m}, \quad i=$ $1,2, \ldots, p-1, \quad \delta_{i}^{*}=\sum_{m=i+1}^{q} \delta_{m}$ ve $i=1,2, \ldots, q-1$ göstermek üzere Eşitlik 8'deki denklem gruplandırıldı̆̆ında aşağıdaki gibi kısaca yeniden yaz1labilmektedir:

$\Delta y_{t}=\phi\left(y_{t-1}-\theta_{i}^{\prime} x_{t}\right)+\sum_{i=1}^{p-1} \lambda_{i}^{*} \Delta y_{t-i}+\sum_{i=0}^{q-1} \delta_{i}^{* \prime} \Delta x_{t-i}+\varepsilon_{t}$

Eşitlik 9'daki denklemde; $\left(\theta=-\left(\frac{\beta}{\phi}\right)\right), \quad\left(y_{t}\right)$ ve $\left(x_{t}\right)$ değişkenleri arasındaki uzun dönemli denge ilişkileri için hesaplanan katsayıları belirtirken, $\left(\lambda_{i}^{*}\right)$ ve $\left(\delta_{i}^{*}\right)$ ise sirasılyla $\left(y_{t}\right)$ ve $\left(x_{t}\right)$ değişkenlerindeki değişimlerin gecikmeli değerleri için hesaplanan kısa dönemli katsayıları göstermektedir. Denklemdeki $(\phi)$ ise $\left(x_{t}\right)$ değişkenindeki değişimler sonucunda $\left(y_{t}\right)$ değişkeninin uzun dönemli ilişkide dengeye yakınsama hızını gösteren ve her zaman negatif değerler alan simetrik hata düzeltme katsayısını belirtmektedir (Pesaran et al., 2001: 290-310).

Shin et al., (2014) tarafindan geliştirilen ve L-ARDL modelinin genişletilmesine dayanan NL-ARDL modeli ise farklı derecelerden bütünleşik olan değişkenler asındaki uzun dönemli ilişkilerin asimetrik 
yönünün incelenebilmesine olanak vermektedir. $\mathrm{Bu}$ yönüyle bağımlı ve açıklayıcı değişkenler arasındaki uzun dönemli doğrusal olmayan ilişkileri araştıran NL-ARDL modeli, açıklayıcı değişkenlerde inceleme döneminde meydana gelen pozitif ve negatif değişmelerin bağımlı değişken üzerinde oluşturduğu etkilerin belirlenebilmesine imkân vermektedir. Eşitlik 8'deki simetrik ve UECM formatındaki denklemin asimetrik ilişkileri içerecek şekilde genişletilmesine dayanan NL-ARDL modeli, aşağıdaki temel regresyon denklemi üzenden araştırlabilmektedir:

$$
\begin{aligned}
& y_{t}=\beta^{+} x_{t}^{+}+\beta^{-} x_{t}^{-}+u_{t} \\
& x_{t}=x_{0}+x_{t}^{+}+x_{t}^{-}
\end{aligned}
$$

Eşitlik $10^{\prime}$ daki, $\left.\beta^{+}\right)$ve $\left(\beta^{-}\right)$sırasıyla $\left(x_{t}^{+}\right)$ve $\left(x_{t}^{-}\right)$ilişkili olan uzun dönemli asimetrik parametreleri ve $\left(u_{t}\right)$ uzun dönemli dengeden sapmalar1 göstermektedir. Eşitlik 11'deki $\left(x_{t}\right)$ ise $\left(x_{t}^{+}\right)$ve $\left(x_{t}^{-}\right)$şeklindeki iki bileşenden oluşmakta ve $\left(x_{t}\right)^{\prime}$ deki pozitif ve negatif değişimlerin kısmi toplamlarını göstermektedir. $\left(x_{t}\right)$ 'deki pozitif ve negatif değişimlerin kısmi toplam süreçlerini gösterecek şekilde $\left(x_{t}\right)$, aşağıdaki gibi ayrıştırılarak yeniden yazilabilmektedir: (Shin et al., 2014: 285-290).

$$
\begin{aligned}
& x_{t}^{+}=\sum_{j=1}^{t} \Delta x_{j}^{+}=\sum_{j=1}^{t} \operatorname{Max}\left(\Delta x_{j}, 0\right) \\
& x_{t}^{-}=\sum_{j=1}^{t} \Delta x_{j}^{-}=\sum_{j=1}^{t} \operatorname{Min}\left(\Delta x_{j}, 0\right)
\end{aligned}
$$

Bu kapsamda, $\left(y_{t}\right)$ ve $\left(x_{t}\right)$ gibi iki zaman serisi değişkeni arasındaki kısa ve uzun dönemli asimetrik ilişkileri araştıran NL-ARDL $(p, q)$ modeli, UECM formatında aşağıdaki gibi ifade edilebilmektedir:

$$
\Delta y_{t}=\phi\left(y_{t-1}-\theta_{1}^{\prime} x_{t}^{+}-\theta_{2}^{\prime} x_{t}^{-}\right)+\sum_{i=1}^{p-1} \lambda_{i} \Delta y_{t-i}+\sum_{i=0}^{q-1} \delta_{1 i}^{* \prime} \Delta x_{t-i}^{+}+\sum_{i=0}^{q-1} \delta_{2 i}^{* \prime} \Delta x_{t-i}^{-}+\varepsilon_{t}
$$

L-ARDL ve NL-ARDL modelleri için sırasıyla Eşitlik 9 ve 14'te tanımlanan denklemlerin tahmininde birbirini izleyen başlıca dört aşama bulunmaktadır. İlk aşamada, bağımlı ve açıklayıcı değişkenleri farklı derecelerde ve en fazla [I(1)] düzeyinde bütünleşik olan L-ARDL ve NLARDL modellerinin Schwarz Bilgi Kriteri (SIC) eşliğinde uygun spesifikasyonları (optimal gecikme uzunlukları) belirlenmektedir. İkinci aşamada, L-ARDL ve NL-ARDL modellerinin bağımlı ve açılayııı değişkenleri arasındaki uzun dönemli simetrik ve asimetrik eş-bütünleşme ilişkileri, Sınır Testi yardımıyla araştırılmaktadır. Burada, L-ARDL ve NLARDL modelleri için hesaplanan FPSS Sınır Testi istatistiklerinin kritik tablo 
değerlerinden büyük olması durumunda, "model değişkenleri arasında eşbütünleşme ilişkisi bulunmamaktadır” şeklindeki temel hipotez reddedilmektedir. L-ARDL ve NL-ARDL modellerindeki değişkenler arasında simetrik ve asimetrik uzun dönemli ilişkilerin bulunması durumunda, üçüncü aşamada Eşitlik 9 ve 14'teki denklemler Sıradan En Küçük Kareler (Ordinary Least Squares-OLS) yöntemiyle tahmin edilmekte ve modellerin açıklayıcı değişkenleri için kısa-uzun dönemli ARDL katsayıları hesaplanmaktadır. Dördüncü ve son aşamada tahmin edilen LARDL ve NL-ARDL modelleri, değişen varyans, otokorelasyon, normallik vb. gibi tanısal testlerden geçirilmekte ve modellerin istikrarlılık koşullarını sağlayıp sağlamadığı araştırılmaktadır.

Birbirini takip eden bu dört aşama izlenilerek orijinal ve genişletilmiş Taylor kurallarının TCMB açısından geçerliliğini belirlemek üzere tahmin edilen L-ARDL ve NL-ARDL modellerine ait bulgular sirasiyla Tablo 4 ve Tablo 5'te sunulmaktadir.

Table 4. L-ARDL ve NL-ARDL Model-1 Tahmin Sonuçları

\begin{tabular}{|c|c|c|c|c|}
\hline Panel A: Sınır Testi İstatistikleri & \multicolumn{2}{|c|}{ L-ARDL } & \multicolumn{2}{|c|}{ NL-ARDL } \\
\hline Model & \multicolumn{2}{|c|}{$(1,1,0)$} & \multicolumn{2}{|c|}{$(4,0,0,3)$} \\
\hline FPSS & \multicolumn{2}{|c|}{$6.21^{*}$} & \multicolumn{2}{|c|}{$7.60^{*}$} \\
\hline \multicolumn{5}{|l|}{ Kritik Değerler (\% 5) } \\
\hline Alt Sinır I(0)-Üst Sinır I(1) & \multicolumn{2}{|c|}{$3.79-4.85$} & \multicolumn{2}{|c|}{$3.23-4.35$} \\
\hline $\begin{array}{c}\text { Panel B: Tanısal Test } \\
\text { İstatistikleri }\end{array}$ & \multicolumn{2}{|c|}{ L-ARDL } & \multicolumn{2}{|c|}{ NL-ARDL } \\
\hline Düzeltilmiş $\mathbf{R}^{2}$ & \multicolumn{2}{|c|}{0.92} & \multicolumn{2}{|r|}{0.93} \\
\hline $\mathbf{F}$ & \multicolumn{2}{|c|}{$218.71[0.000]$} & \multicolumn{2}{|c|}{$91.92[0.000]$} \\
\hline $\mathbf{R R}$ & \multicolumn{2}{|c|}{$0.203[0.839]$} & \multicolumn{2}{|c|}{$1.251[0.216]$} \\
\hline LM & \multicolumn{2}{|c|}{$1.492[0.226]$} & \multicolumn{2}{|c|}{$0.068[0.795]$} \\
\hline ARCH & \multicolumn{2}{|c|}{$0.003[0.955]$} & \multicolumn{2}{|c|}{$0.156[0.694]$} \\
\hline CS & & S & & S \\
\hline \multirow[b]{2}{*}{$\begin{array}{c}\text { Panel C: Kisa Dönemli } \\
\text { Tahminler }\end{array}$} & \multicolumn{2}{|c|}{ L-ARDL } & \multicolumn{2}{|c|}{ NL-ARDL } \\
\hline & $\begin{array}{c}\text { Katsay } \\
1\end{array}$ & $\begin{array}{l}\text { Standart } \\
\text { Hata }\end{array}$ & $\begin{array}{c}\text { Katsay } \\
1\end{array}$ & $\begin{array}{l}\text { Standart } \\
\text { Hata }\end{array}$ \\
\hline$F O_{t-1}$ & $0.893^{a}$ & $0.039[0.000]$ & $0.9299^{a}$ & $0.118[0.000]$ \\
\hline$F O_{t-2}$ & - & - & -0.139 & $0.166[0.402]$ \\
\hline $\mathrm{FO}_{t-3}$ & - & - & $-0.343^{b}$ & $0.165[0.042]$ \\
\hline $\mathrm{FO}_{t-4}$ & - & - & $0.444^{\mathrm{a}}$ & $0.113[0.000]$ \\
\hline$E A_{t}$ & $4.498^{\mathrm{a}}$ & $1.678[0.009]$ & - & - \\
\hline$E A_{t-1}$ & -2.921 & $1.532[0.061]$ & - & - \\
\hline$E A_{t}^{+}$ & - & - & $3.095^{\mathrm{a}}$ & $0.914[0.001]$ \\
\hline$E A_{t}^{-}$ & - & - & $2.762^{a}$ & $0.902[0.003]$ \\
\hline$Y A_{t}$ & $2.150^{\mathrm{a}}$ & $0.664[0.002]$ & $1.541^{\mathrm{b}}$ & $0.703[0.045]$ \\
\hline$Y A_{t-1}$ & - & - & -0.279 & $1.428[0.846]$ \\
\hline$Y A_{t-2}$ & - & - & 0.409 & 1.778 [0.819] \\
\hline$Y A_{t-3}$ & - & - & $3.493^{b}$ & $1.453[0.019]$ \\
\hline \multirow{3}{*}{$\begin{array}{c}\text { C } \\
\text { Panel D: Uzun Dönemli } \\
\text { Tahminler }\end{array}$} & $0.229 \mathrm{~b}$ & $0.097[0.021]$ & -0.020 & $0.259[0.938]$ \\
\hline & \multicolumn{2}{|c|}{ L-ARDL } & \multicolumn{2}{|c|}{ NL-ARDL } \\
\hline & Katsay & Standart & Katsay & Standart \\
\hline
\end{tabular}




\begin{tabular}{c|c|c|c|c|}
\hline & $\mathbf{1}$ & Hata & 1 & Hata \\
\hline $\boldsymbol{E} \boldsymbol{A}_{\boldsymbol{t}}$ & $4.499^{\mathrm{a}}$ & $1.571[0.006]$ & - & - \\
\hline $\boldsymbol{E} \boldsymbol{A}_{\boldsymbol{t}}^{+}$ & - & - & $3.095^{\mathrm{a}}$ & $0.914[0.001]$ \\
\hline $\boldsymbol{E} \boldsymbol{A}_{\boldsymbol{t}}^{-}$ & - & - & $2.762^{\mathrm{a}}$ & $0.902[0.003]$ \\
\hline $\boldsymbol{Y \boldsymbol { A } _ { \boldsymbol { t } }}$ & $2.156^{\mathrm{a}}$ & $0.664[0.002]$ & $5.163^{\mathrm{a}}$ & $1.078[0.000]$ \\
\hline $\boldsymbol{C}$ & $0.229^{\mathrm{a}}$ & $0.064[0.000]$ & -0.020 & $0.250[0.419]$ \\
\hline $\boldsymbol{E} \boldsymbol{C} \boldsymbol{M}_{\boldsymbol{t}-\mathbf{1}}$ & $-0.107^{\mathrm{a}}$ & $0.024[0.000]$ & $-0.109^{\mathrm{a}}$ & $0.0193[0.000]$ \\
\hline
\end{tabular}

Not: Modellerde değişkenlerin hesaplanan katsayılarının önündeki “a” ve “b” simgeleri katsaylara ait t-istatistiklerinin sirasiyla $\% 1$ ve $\% 5$ önem düzeyinde anlamlı olduğunu belirtmektedir. Tabloda "П" parantezi içindeki değerler katsayılara ait olasılıkları ve " $\mathrm{t}$ " simgesi $(\mathrm{t}=0)$ olmak üzere katsayıların SIC ile belirlenen gecikme düzenini göstermektedir. Tablodaki FPSS test istatistiklerinin önündeki “*” simgesi model değişkenleri arasında \% 1 anlamlılık düzeyinde eş-bütünleşme ilişkisinin bulunduğunu belirtmektedir.

Orijinal Taylor kuralına ait Tablo 4'teki Panel A bulguları, L-ARDL ve NL-ARDL modellerinin bağımlı (FO) ve açıklayıcı (EA, YA) değişkenleri için genelden özele yaklaşımı ve SIC kullanılarak maximum 6 gecikme uzunluğundaki spesifikasyonlarından elde edilen Sınır Testi istatistiklerini göstermektedir. Panel A'daki bulgular incelendiğinde, L-ARDL $(1,1,0)$ ve NL-ARDL (4, 0, 0, 3) modellerinin bağımlı ve açıklayıcı değişkenleri arasında hem simetrik hem de asimetrik açıdan uzun dönemde eşbütünleşme ilişkilerinin bulunduğu görülmektedir. Bu sonucu, L-ARDL ve NL-ARDL modelleri için hesaplanan FPSS Sınır Testi istatistiklerinin, Pesaran et al., (2001) çalışmasından alınan kritik tablo değerlerinin Alt ve Üst sinırlarından \% 5 önem düzeyinde büyük olmasıyla ve temel hipotezlerin reddedilmesiyle ulaşılmaktadır.

Tablo 4'teki Panel B bulguları, L-ARDL ve NL-ARDL modelleri için tanımlama hatası (Ramsey Reset-RR), otokorelasyon (Lagrange MultiplierLM), değişen varyans (Autoregressive Conditional Heteroscedasticity$\mathrm{ARCH}$ ), yapısal istikrarlılık (Cusum-CS), F ve Düzeltilmiş R2 şeklindeki tanısal test istatistiklerini göstermektedir. Bu kapsamda Panel B'deki bulgular incelendiğinde, bağımlı değişkeninin açıklanma gücünü gösteren Düzeltilmiş R2 değerlerinin yüksek ve F-istatistiklerinin anlamlı olduğu L-ARDL ve NLARDL modellerinin tanısal açıdan istikrarlıı koşullarını da sağladığ görülmektedir. L-ARDL ve NL-ARDL modellerinde; tanımlama hatalarının, otokorelasyonun ve değişen varyansın bulunmadığı ve yapısal açıdan istikrarın bulunduğu Panel B'deki bulgulardan anlaşılabilmektedir. Bu sonuçlara RR, LM, ARCH tanısal testleri için hesaplanan test istatistikleri olasilık değerlerinin 0.05 'ten büyük olduğunun ve CS test sonuçlarının istikrarlı (S) olduğunun belirlenmesiyle ulaşılmaktadır.

Tablo 4'teki Panel D bulguları hata düzeltme katsayıları açısından incelendiğinde ise L-ARDL ve NL-ARDL modellerinde değişkenler arasındaki uzun dönemli yakınsamanın düzeyini gösteren $\left(\mathrm{ECM}_{\mathrm{t}-1}\right)$ 
katsayılarının, sırasıyla $(-0.107)$ ve $(-0.109)$ olarak hesaplandığ1 ve istatistiki açıdan anlamlı oldukları görülmektedir. Bu durum L-ARDL ve NL-ARDL modellerinde değişkenler arasında simetrik veya asimetrik açıdan kısa dönemde meydana gelen şokların etkilerinin uzun dönemde ortadan kalkacağını ve değişkenlerin birlikte yürüyüşlerinin tekrar dengeye geleceğini göstermektedir.

Uzun dönemde eş-bütünleşik ve tanısal açıdan güvenilir olduğu belirlenen orijinal Taylor kuralina ait L-ARDL ve NL-ARDL modellerinin açıklayıcı değişkenleri için hesaplanan kısa ve uzun dönemli simetrik ve asimetrik katsayılar ise sirasiyla Tablo 4'ün $C$ ve $D$ panellerinde sunulmaktadır. Tablo 4'teki Panel $\mathrm{C}$ ve $\mathrm{D}$ bulguları incelendiğinde, L-ARDL ve NL-ARDL modellerinde EA, EA+, EA- ve YA açıklayıcı değişkenlerinin düzey değerlerine ait kısa ve uzun dönemli simetrik ve asimetrik katsayıların beklentilerle uyumlu olacak şekilde pozitif yönlü ve istatistiki açıdan anlamlı olarak hesaplandıkları görülmektedir. Bunun yanı sıra Panel C'deki bulgular incelendiğinde, L-ARDL ve NL-ARDL modellerinde FO bağımlı değişkeni ile EA ve YA açıklayıcı değişkenlerinin gecikmeli değerlerine ait kısa dönemli simetrik ve asimetrik katsayıların gecikmelere göre değişen bir şekilde hesaplandığ1 görülmektedir. Nitekim Panel C'deki bulgular incelendiğinde, L-ARDL ve NL-ARDL modellerinde FO, EA ve YA değişkenlerinin gecikmeli değerlerine ait kısa dönemli simetrik ve asimetrik katsayıların gecikmelere göre pozitif/negatif yönlü ve istatistiki açıdan anlamlı/anlamsız olacak şekilde hesaplandığı anlaşılmaktadır. $\mathrm{Bu}$ durum, Türkiye ekonomisinde inceleme döneminde enflasyon ve üretim açı̆̆ında meydana gelen simetrik ve/veya asimetrik değişimlerin para piyasası politika faizleri üzerinde gecikmelere göre kısa dönemde artırıcı veya azaltıcı bir şekilde etkili olduğunu göstermektedir.

Diğger yandan Panel $C$ ve $\mathrm{D}$ bulguları incelendiğinde, L-ARDL modelinde EA ve YA açılayıcı değişkenlerinin düzey değerlerine ait kısa dönemli simetrik katsayıların (4.498) ve (2.150) olarak ve uzun dönemli simetrik katsayıların da (4.499) ve (2.156) olarak hesaplandığ anlaşılmaktadır. NL-ARDL modelinde ise EA+, EA- ve YA açıklayıc1 değişkenlerinin düzey değerlerine ait kısa dönemli simetrik ve asimetrik katsayıların (3.095), (2.762) ve (1.514) olarak ve uzun dönemli simetrik ve asimetrik katsayıların da (3.095), (2.762) ve (5.163) olarak hesaplandığı Panel $\mathrm{C}$ ve D'den izlenebilmektedir. Bu sonuçlar, Türkiye ekonomisinde enflasyon ve üretim açığında kısa ve uzun dönemde meydana gelen \% 1'lik bir simetrik değişim (artış) karşısında (gerçekleşen enflasyonun hedeflenen enflasyonu ve/veya gerçekleşen üretim düzeyinin potansiyel üretim düzeyini aşması durumunda) TCMB tarafindan para piyasası politika faiz oranlarının sirasiyla yaklaşık ( $\%$ 4.5) ve ( $\%$ 2.2) olarak artırılması gerektiğini göstermektedir. Benzer bir şekilde sonuçlar, Türkiye ekonomisinde enflasyon ve üretim açığında kısa ve uzun dönemde meydana gelen \% 1'lik bir simetrik ve 
asimetrik değişim (artış/azalış) karşısında ise TCMB tarafindan para piyasası politika faiz oranlarının sırasıyla yaklaşık (\% 3.1), (\% 2.8) ve (\% 1.5-5.2) olarak artırılması gerektiğini belirtmektedir. Bununla birlikte sonuçlar, 2002 yllından bu yana enflasyon hedeflemesi rejimini benimsemiş olan TCMB'nin fiyat istikrarının sağlanıp sürdürülmesi temel amacına uyumlu bir şekilde para piyasası politika faiz oranlarının kısa ve uzun dönemde enflasyon açığına daha fazla duyarlı olduğunu göstermektedir. Tüm bu sonuçlar, inceleme döneminde doğrusal ve doğrusal olmayan formlarda orijinal Taylor kuralının TCMB açısından enflasyon ve üretim açı̆̆ı itibariyle geçerli olduğunu ve TCMB tarafindan para piyasası politika faiz oranlarının enflasyon ve üretim açığında kısa-uzun dönemde oluşan simetrik-asimetrik değişimlere göre belirlendiğini göstermektedir.

Tablo 5. L-ARDL ve NL-ARDL Model-2 Tahmin Sonuçları

\begin{tabular}{|c|c|c|c|c|}
\hline Panel A: Sınır Testi İstatistikleri & \multicolumn{2}{|c|}{ L-ARDL } & \multicolumn{2}{|c|}{ NL-ARDL } \\
\hline Model & \multicolumn{2}{|c|}{$(1,0,0,1)$} & \multicolumn{2}{|c|}{$(1,0,0,0,1)$} \\
\hline FPSS & \multicolumn{2}{|c|}{$5.24^{*}$} & \multicolumn{2}{|c|}{$4.47^{*}$} \\
\hline Kritik Değerler (\% 5) & & & & \\
\hline Alt Sınır I(0)-Üst Sınır I(1) & \multicolumn{2}{|c|}{$3.23-4.35$} & \multicolumn{2}{|c|}{$2.86-4.01$} \\
\hline Panel B: Tanısal Test İstatistikleri & \multicolumn{2}{|c|}{ L-ARDL } & \multicolumn{2}{|c|}{ NL-ARDL } \\
\hline Düzeltilmiş $\mathbf{R}^{2}$ & \multicolumn{2}{|r|}{0.93} & \multicolumn{2}{|r|}{0.93} \\
\hline F & \multicolumn{2}{|c|}{$180.22[0.000]$} & \multicolumn{2}{|c|}{$151.02[0.000]$} \\
\hline $\mathbf{R R}$ & \multicolumn{2}{|c|}{$1.072[0.288]$} & \multicolumn{2}{|c|}{$0.418[0.677]$} \\
\hline LM & \multicolumn{2}{|c|}{$1.881[0.175]$} & \multicolumn{2}{|c|}{$1.139[0.289]$} \\
\hline ARCH & \multicolumn{2}{|c|}{$0.005[0.942]$} & \multicolumn{2}{|c|}{$0.061[0.806]$} \\
\hline CS & \multirow{2}{*}{\multicolumn{2}{|c|}{$\begin{array}{c}\text { S } \\
\text { L-ARDL }\end{array}$}} & \multirow{2}{*}{\multicolumn{2}{|c|}{$\begin{array}{c}\text { S } \\
\text { NL-ARDL }\end{array}$}} \\
\hline \multirow{2}{*}{ Panel C: Kısa Dönemli Tahminler } & & & & \\
\hline & Katsayı & Standart Hata & Katsay1 & Standart Hata \\
\hline$F O_{t-1}$ & $0.889^{\mathrm{a}}$ & $0.039[0.000]$ & $0.919^{\mathrm{a}}$ & $0.047[0.000]$ \\
\hline$E A_{t}$ & 1.067 & $1.171[0.365]$ & - & - \\
\hline$E A_{t}^{+}$ & - & - & 1.412 & $1.207[0.247]$ \\
\hline $\boldsymbol{E A}_{t}^{-}$ & - & - & 0.901 & $1.178[0.447]$ \\
\hline$Y A_{t}$ & $2.435^{\mathrm{a}}$ & $0.675[0.001]$ & $2.539^{\mathrm{a}}$ & $0.680[0.000]$ \\
\hline$D A_{t}$ & $1.253^{\mathrm{b}}$ & $0.492[0.013]$ & $1.304^{\mathrm{b}}$ & $0.493[0.010]$ \\
\hline$D A_{t-1}$ & -0.728 & $0.502[0.152]$ & -0.739 & $0.501[0.145]$ \\
\hline $\mathrm{C}$ & $0.237^{\mathbf{b}}$ & $0.096[0.016]$ & -0.026 & $0.207[0.898]$ \\
\hline \multirow{2}{*}{ Panel D: Uzun Dönemli Tahminler } & \multicolumn{2}{|c|}{ L-ARDL } & \multicolumn{2}{|c|}{ NL-ARDL } \\
\hline & Katsay1 & Standart Hata & Katsay1 & Standart Hata \\
\hline$E A_{t}$ & 1.067 & $1.171[0.365]$ & - & - \\
\hline $\boldsymbol{E A}_{t}^{+}$ & - & - & 1.412 & $1.207[0.247]$ \\
\hline$E A_{t}^{-}$ & - & - & 0.901 & $1.178[0.447]$ \\
\hline$Y A_{t}$ & $2.434^{a}$ & $0.674[0.001]$ & $2.556^{\mathrm{a}}$ & $0.680[0.000]$ \\
\hline$D A_{t}$ & $1.252^{\mathrm{a}}$ & $0.428[0.005]$ & $1.362^{\mathrm{a}}$ & $0.426[0.003]$ \\
\hline C & $0.236^{a}$ & $0.062[0.001]$ & -0.026 & $0.026[0.322]$ \\
\hline$E C M_{t-1}$ & $-0.110^{\mathrm{a}}$ & $0.024[0.000]$ & $-0.080^{\mathrm{a}}$ & $0.016[0.000]$ \\
\hline
\end{tabular}

Not: Tablo 4'teki açıklamalara bakınız.

Genişletilmiş Taylor kuralına ait Tablo 5'teki Panel A bulguları, L-ARDL ve NL-ARDL modellerinin bağımlı (FO) ve açıklayıcı (EA, YA, DA) değişkenleri için genelden özele yaklaşımı ve SIC kullanılarak maximum 6 gecikme uzunluğundaki spesifikasyonlarından elde edilen Sınır Testi 
istatistiklerini göstermektedir. Panel A'daki bulgular incelendiğinde, LARDL $(1,0,0,1)$ ve NL-ARDL (1, 0, 0, 0, 1) modellerinin bağıml ve açıklayıcı değişkenleri arasında hem simetrik hem de asimetrik açıdan uzun dönemde eş-bütünleşme ilişkilerinin bulunduğu görülmektedir. Bu sonucu, L-ARDL ve NL-ARDL modelleri için hesaplanan FPSS Sınır Testi istatistiklerinin, Pesaran et al., (2001) çalışmasından alınan kritik tablo değerlerinin Alt ve Üst sinırlarından \% 5 önem düzeyinde büyük olmasıyla ve temel hipotezlerin reddedilmesiyle ulaşılmaktadır.

Tablo 5'teki Panel B bulguları, L-ARDL ve NL-ARDL modelleri için tanımlama hatası (Ramsey Reset-RR), otokorelasyon (Lagrange MultiplierLM), değişen varyans (Autoregressive Conditional HeteroscedasticityARCH), yapısal istikrarlılık (Cusum-CS), F ve Düzeltilmiş R2 şeklindeki tanısal test istatistiklerini göstermektedir. Bu kapsamda Panel B'deki bulgular incelendiğinde, bağımlı değişkeninin açıklanma gücünü gösteren Düzeltilmiş R2 değerlerinin yüksek ve F-istatistiklerinin anlamlı olduğu L-ARDL ve NLARDL modellerinin tanısal açıdan istikrarlılık koşullarını da sağladığı görülmektedir. L-ARDL ve NL-ARDL modellerinde; tanımlama hatalarının, otokorelasyonun ve değişen varyansın bulunmadığı ve yapısal açıdan istikrarın bulunduğu Panel B'deki bulgulardan anlaşılabilmektedir. Bu sonuçlara RR, LM, ARCH tanısal testleri için hesaplanan test istatistikleri olasılık değerlerinin 0.05 'ten büyük olduğunun ve CS test sonuçlarının istikrarlı (S) olduğunun belirlenmesiyle ulaşılmaktadır.

Tablo 5'teki Panel D bulguları hata düzeltme katsayıları açısından incelendiğinde ise L-ARDL ve NL-ARDL modellerinde değişkenler arasındaki uzun dönemli yakınsamanın düzeyini gösteren $\left(\mathrm{ECM}_{\mathrm{t}-1}\right)$ katsayılarının, sirasıyla $(-0.110)$ ve $(-0.080)$ olarak hesaplandığ1 ve istatistiki açıdan anlamlı oldukları görülmektedir. Bu durum L-ARDL ve NL-ARDL modellerinde değişkenler arasında simetrik veya asimetrik açıdan kısa dönemde meydana gelen şokların etkilerinin uzun dönemde ortadan kalkacağını ve değişkenlerin birlikte yürüyüşlerinin tekrar dengeye geleceğini göstermektedir.

Uzun dönemde eş-bütünleşik ve tanısal açıdan güvenilir olduğu belirlenen genişletilmiş Taylor kuralına ait L-ARDL ve NL-ARDL modellerinin açıklayıcı değişkenleri için hesaplanan kısa ve uzun dönemli simetrik ve asimetrik katsayılar ise sirasiyla Tablo 5 'in $C$ ve $D$ panellerinde sunulmaktadır. Tablo 5'teki Panel $\mathrm{C}$ ve $\mathrm{D}$ bulguları incelendiğinde, L-ARDL ve NL-ARDL modellerinde YA ve DA açıklayıcı değişkenlerinin düzey değerlerine ait kısa ve uzun dönemli simetrik ve asimetrik katsayıların beklentilerle uyumlu olacak şekilde pozitif yönlü ve istatistiki açıdan anlamlı olarak hesaplandıkları görülmektedir. Buna karşılık Panel $C$ ve D bulguları incelendiğinde, L-ARDL ve NL-ARDL modellerinde EA, EA+ ve EAaçıklayıcı değişkenlerinin düzey değerlerine ait kısa ve uzun dönemli simetrik 
ve asimetrik katsayıların beklentilerle uyumlu olacak şekilde pozitif yönlü ve/fakat istatistiki açıdan anlamsız olarak hesaplandıkları anlaşılmaktadır. Bunun yanı sıra Panel C'deki bulgular incelendiğinde, L-ARDL ve NLARDL modellerinde $\mathrm{FO}$ ve DA değişkenlerinin gecikmeli değerlerine ait kısa dönemli simetrik ve asimetrik katsayıların pozitif yönlü/negatif yönlü ve istatistiki açıdan anlamlı/anlamsız olarak hesaplandıkları izlenmektedir. Bu durum, Türkiye ekonomisinde üretim ve döviz kuru açığında kisa ve uzun dönemde meydana gelen simetrik ve/veya asimetrik değişimlerin para piyasası politika faizleri üzerinde etkili olduğunu gösterirken, enflasyon açığının düzey ve döviz kuru açı̆̆ının gecikmeli değerlerinin ise para piyasası politika faizleri üzerinde etkili olmadığını ortaya koymaktadır.

$\mathrm{Bu}$ kapsamda, Panel $\mathrm{C}$ ve $\mathrm{D}$ bulguları incelendiğinde, L-ARDL modelinde YA ve DA açılkayıcı değişkenlerinin düzey değerlerine ait kısa dönemli simetrik katsayıların (2.435) ve (1.253) olarak ve uzun dönemli simetrik katsayıların da (2.434) ve (1.252) olarak hesaplandı̆̆1 anlaşılmaktadır. NL-ARDL modelinde ise YA ve DA açıllayıcı değişkenlerinin düzey değerlerine ait kısa dönemli simetrik ve asimetrik katsayların (2.539) ve (1.304) olarak ve uzun dönemli simetrik ve asimetrik katsayıların da (2.556) ve (1.362) olarak hesaplandığı Panel C ve D'den izlenebilmektedir. Bu sonuçlar, Türkiye ekonomisinde üretim ve döviz kuru açığında kısa ve uzun dönemde meydana gelen \% 1'lik bir simetrik değişim (artış) karşısında (gerçekleşen üretim/döviz kuru düzeyinin potansiyel üretim/döviz kuru düzeyini aşması durumunda) TCMB tarafindan para piyasası politika faiz oranlarının sırasıyla yaklaşık (\% 2.4) ve (\% 1.3) olarak artırlması gerektiğini göstermektedir. Benzer bir şekilde sonuçlar, Türkiye ekonomisinde üretim ve döviz kuru açığında kısa ve uzun dönemde meydana gelen \% 1'lik bir simetrik ve asimetrik değişim (artış/azalış) karşısında ise TCMB tarafindan para piyasası politika faiz oranlarının sırasıyla yaklaşı $\left(\begin{array}{lllll}\% & 2.5\end{array}\right)$ ve $\left(\begin{array}{lll}\% & 1.3\end{array}\right)$ olarak artırılması gerektiğini belirtmektedir. Bununla birlikte sonuçlar, 2002 y1lından bu yana enflasyon hedeflemesi rejimini benimsemiş olan TCMB'nin fiyat istikrarının sağlanıp sürdürülmesi temel amaciyla örtüşmemekte ve para piyasası politika faiz oranlarının kısa ve uzun dönemde enflasyon açığından ziyade üretim ve döviz kuru açıklarına duyarlı olduğunu göstermektedir. Tüm bu sonuçlar, inceleme döneminde doğrusal ve doğrusal olmayan formlarda genişletilmiş Taylor kuralının TCMB açısından sadece üretim ve döviz kuru açığı itibariyle geçerli olduğunu ve TCMB tarafindan para piyasası politika faiz oranlarının üretim ve döviz kuru açı̆̆ında kısa-uzun dönemde oluşan simetrik-asimetrik değişimlere göre belirlendiğini göstermektedir.

\section{Sonuç}

Günümüzde enflasyon hedeflemesi rejimini benimsemiş olan merkez bankalarının para politikası uygulamalarını önemli ölçüde şekillendiren 
orijinal ve genişletilmiş Taylor kuralları, enflasyon haddi, üretim düzeyi (hâsıla) ve döviz kurlarındaki değişimlerden kaynaklı etkilere para piyasası politika faiz oranları araciluğyla vermesi gereken tepkilerin derecesini göstermektedir. Bu kapsamda, para piyasası politika faiz oranı ile enflasyon haddi, üretim düzeyi ve döviz kurları arasındaki ilişkileri kurala dayalı olarak açılamak üzere John B. Taylor (1993-2001) tarafından geliştirilen orijinal ve genişletilmiş Taylor kuralları, para politikalarının sistematikleştirilmesini sağlamakta ve merkez bankalarının politika uygulamalarının öngörüsünü artırmaktadir.

$\mathrm{Bu}$ noktadan hareketle çalışmada, 2002 yllından bu yana enflasyon hedeflemesi rejimini benimsemiş olan Türkiye Cumhuriyet Merkez Bankası (TCMB) tarafindan para politikasının temel aracı olarak kullanılan politika faiz oranlarının belirlenmesinde orijinal ve genişletilmiş Taylor kurallarının geçerli olup olmadığının ampirik olarak incelenmesi amaçlanmaktadır. Bu amaçla çalışmada orijinal ve genişletilmiş Taylor kurallarının TCMB açısından 2002:Q1-2019Q:2 dönemindeki geçerliliği, doğrusal ve doğrusal olmayan zaman serisi analizi kapsaminda ekonometrik olarak incelenmektedir. Çalışmada, orijinal ve genişletilmiş Taylor kurallarının TCMB açısından geçerliliğini belirlemek üzere doğrusal ve doğrusal olmayan zaman serisi analizleri kullanılarak tahmin edilen modellerin, literatürdeki ampirik çalışmalarla ve TCMB'nin para politikası amaçlarıly uyumlu bulguları şu şekilde özetlenebilmektedir:

Çalışmada orijinal Taylor kuralının geçerliliğinin doğrusal zaman serisi analizi kullanılarak araştırıldığı modellerde, TCMB tarafindan para piyasası politika faiz oranlarının enflasyon ve üretim açığında kısa ve uzun dönemde meydana gelen \% 1'lik bir simetrik değişim (artıs) karşısında sırasıyla yaklaşık $(\% 4.5)$ ve (\% 2.2) olarak artırılması gerektiği belirlenmiştir. Orijinal Taylor kuralının geçerliliğinin doğrusal olmayan zaman serisi analizi kullanılarak araştırıldığ modellerde ise TCMB tarafından para piyasası politika faiz oranlarının enflasyon ve üretim açığında kısa ve uzun dönemde meydana gelen \% 1'lik bir simetrik-asimetrik değişim (artış/azalış) karşısında sırasıyla yaklaşı (\% 2.8-3.1) ve (\% 1.5-5.2) aralı̆̆ında artırılması gerektiği tespit edilmiştir. Bu sonuçlar, inceleme döneminde doğrusal ve doğrusal olmayan formlarda orijinal Taylor kuralının TCMB açısından enflasyon ve üretim açığı itibariyle geçerli olduğunu ve TCMB tarafindan para piyasası politika faiz oranlarının enflasyon ve üretim açı̆̆ında kısa-uzun dönemde oluşan simetrik-asimetrik değişimlere göre belirlendiğini göstermektedir. Bununla birlikte sonuçlar, 2002 yllından bu yana enflasyon hedeflemesi rejimini benimsemiş olan TCMB'nin fiyat istikrarının sağlanıp sürdürülmesi temel amacına uyumlu bir şekilde para piyasası politika faiz oranlarının kısa ve uzun dönemde enflasyon açı̆̆ına daha fazla duyarlı olduğunu ortaya koymaktadır. 
Buna karşılık çalışmada genişletilmiş Taylor kuralının geçerliliğinin doğrusal ve doğrusal olmayan zaman serisi analizleri kullanılarak araştırıldığ modellerde, TCMB tarafindan para piyasası politika faiz oranlarının belirlenmesinde enflasyon açığındaki simetrik-asimetrik değişimlerin etkili olmadığı, üretim ve döviz kuru açığındaki simetrik-asimetrik değişimlerin ise etkili olduğu sonucuna ulaşılmıştır. Bu kapsamda çalışmada genişletilmiş Taylor kuralının geçerliliğinin doğrusal zaman serisi analizi kullanılarak araştırıldığı modellerde, TCMB tarafindan para piyasası politika faiz oranlarının üretim ve döviz kuru açığında kısa ve uzun dönemde meydana gelen \% 1'lik bir simetrik değişim (artıs) karşısında sırasıyla yaklaşık (\% 2.4) ve (\% 1.3) olarak artırlması gerektiği belirlenmiştir. Genişletilmiş Taylor kuralının geçerliliğinin doğrusal olmayan zaman serisi analizi kullanılarak araştırıldığ modellerde ise TCMB tarafından para piyasası politika faiz oranlarının üretim ve döviz kuru açığında kısa ve uzun dönemde meydana gelen \% 1'lik bir simetrik-asimetrik değişim (artış/azalış) karşısında sırasıyla yaklaşı (\% 2.5) ve (\% 1.3) olarak artırlması gerektiği tespit edilmiştir. Bu sonuçlar, inceleme döneminde doğrusal ve doğrusal olmayan formlarda genişletilmiş Taylor kuralının TCMB açısından sadece üretim ve döviz kuru açığı itibariyle geçerli olduğunu ve TCMB tarafindan para piyasası politika faiz oranlarının üretim ve döviz kuru açığında kısa-uzun dönemde oluşan simetrik-asimetrik değişimlere göre belirlendiğini göstermektedir. Bununla birlikte sonuçlar, 2002 yllindan bu yana enflasyon hedeflemesi rejimini benimsemiş olan TCMB'nin fiyat istikrarının sağlanıp sürdürülmesi temel amacıyla örtüşmemekte ve para piyasası politika faiz oranlarının kısa ve uzun dönemde enflasyon açığından ziyade üretim ve döviz kuru açığına duyarlı olduğunu ortaya koymaktadır. Bu durum, Türkiye gibi gelişmekte olan dişa açık ekonomilerde, enflasyonun döviz kurlarındaki değişimlere önemli ölçüde duyarlı olmasından kaynaklanmakta ve fiyat istikrarının sağlanıp sürdürülebilmesinin döviz kurlarında istikrarlllı̆̆ının sağlanabilmesine bağlı olmasından ileri gelmektedir. Nitekim üretimi büyük ölçüde ithal girdilere bağlı olan ve tüketimi ise belli ölçüde ithal çıtıllara yönelen Türkiye gibi gelişmekte olan dışa açık ekonomilerde, finansal istikrar bileşeni olarak döviz kurlarındaki değişimler enflasyon üzerinde önemli ölçüde etkili olmaktadır. Taylor (2001) çalışmasında da belirtildiği üzere döviz kuralarındaki değişimlerin enflasyondaki değişimleri dolaylı olarak içerdiği anlamına gelen bu durum, doğrusal ve doğrusal olmayan formlarda genişletilmiş Taylor kuralının TCMB açısından döviz kuru/enflasyon açığı itibariyle geçerli olmasını/olmamasını açıklayabilmektedir.

$\mathrm{Bu}$ açıklamalar dikkate alındığında çalışmada tanımlı modellerden elde edilen sonuçlar, hem doğrusal hem de doğrusal olmayan formlarda orijinal ve genişletilmiş Taylor kurallarının TCMB açısından enflasyon, üretim ve döviz kuru açıları itibariyle geçerli olduğu şeklinde yorumlanabilmektedir. Orijinal ve genişletilmiş Taylor kurallarının doğrusal ve doğrusal olmayan 
formlarda TCMB açısından geçerli olması ise Türkiye ekonomisinde enflasyon hedeflemesi rejiminin benimsendiği 2002-2019 döneminde TCBM tarafindan para politikası stratejilerinin orijinal ve genişletilmiş Taylor kurallarının dikkate alınmasıyla tasarlandığına işaret etmektedir. Bununla birlikte orijinal ve genişletilmiş Taylor kurallarının doğrusal ve doğrusal olmayan formlarda TCMB açısından geçerli olması, TCBM tarafından para piyasası politika faiz oranlarının enflasyon, üretim ve döviz kuru açıklarındaki değişimlerin etkilerinin dikkate alınmasıyla belirlendiği anlamını taşımaktadır. Bu durum enflasyon hedeflemesi rejiminin benimsendiği 20022019 döneminde TCBM tarafından para politikası stratejileri tasarlanırken ve para piyasası politika faiz oranları kullanılırken, temel amaç olarak belirlenen fiyat istikrarının yanında hasılanın ve finansal istikrarın da belli ölçülerde gözetildiğini göstermektedir.

TCMB tarafindan para piyasası politika faiz oranlarının orijinal ve genişletilmiş Taylor kuralları çerçevesinde, enflasyon, üretim ve döviz kurlarındaki değişimlere göre belirlenmesi ise enflasyon hedeflemesi rejiminin başarı düzeyini artırabilmek üzere parasal politikalarda kurala dayalı uygulamaların işleyişiyle uyumlu bir dizi iyileştirmenin ve geliştirmenin yapılmasının gerekliğine işaret etmektedir. Bu kapsamda, TCMB tarafindan para politikalarının mevcut şeffaflık ve öngörülebilirlik seviyesinin piyasa katılımcılarının beklentilerini karşılayabilme ve yönlendirebilme düzeyinin artırılabilmesine-geliştirilebilmesine dönük para politikası düzenlemelerin yapılması gereklilik arz etmektedir. Bu amaçla TCMB tarafından 2006 yllından itibaren uygulanmakta olan açı enflasyon hedeflemesi rejiminin kredibilitesinin etkili ve tutarlı enflasyon öngörü yöntemleriyle artırılabilmesine, kamuoyuna ilan edilmesindeki iletişim politikalarının veri ve bilgi seti ile duruyu sıklığının genişletilmesiyle etkinliğinin arıtılabilmesine vb. yönelik para politikası düzenlemelerin yapılması gerekmektedir. Böylelikle, orijinal ve genişletilmiş Taylor kuralları çerçevesinde TCMB'nin enflasyon, üretim ve döviz kurlarındaki değişimlere para piyasası politika faizleri üzerinden vermesi gereken tepkilerin derecesinin belirlenebilmesi ve fiyat istikrarı üzerinde etkili olan diğer koşullar veri iken enflasyon hedeflemesi rejiminin başarı düzeyinin belli ölçüde artırılabilmesi mümkün olabilecektir. Diğer yandan, orijinal ve genişletilmiş Taylor kurallarının TCMB açısından geçerliliğini konu edinecek ampirik çalışmalarda, Tüketici Fiyat Endeksi'nin alt bileşenlerinin ve nominal efektif döviz kurlarının kullanılmasının ve Taylor tipi kuralların geriye ve ileriye dönük varyasyonlarının doğrusal ve doğrusal olmayan yöntemlerle tahmin edilmesinin ilgili literatürün gelişimine katk1 sağlayacağ1 değerlendirilmektedir. 


\section{Kaynakça}

Aguiar-Conraria, L., Martins, M. M., \& Soares, M. J. (2018). "Estimating the Taylor rule in the time-frequency domain". Journal of Macroeconomics, 57, 122-137.

Akat, A.S. (2004). "Dalgalı Kur ve Para Politikası: Bir Parasal Kural Önerisi”. Gülten Kåggan'a Armağan: Cumburiyet Dönemi Türkiye Ekonomisi. İstanbul Bilgi Üniversitesi Yayınları. İstanbul. 1-19.

Akdeniz, C. ve Çatık, A. N. (2019). "Finansal Koşulların Taylor Kuralının Geçerliliği Üzerindeki Etkisi: Türkiye Üzerine Ampirik Bulgular”. TES AM Akademi Dergisi, Türkiye Ekonomisi Özel sayısı, 107-126.

Aklan, N. A. ve Nargeleçekenler, M. (2008).“Taylor Kuralı: Türkiye Üzerine Bir Değerlendirme”. Ankara Üniversitesi SBF Dergisi. 63(02):21-41.

Albayrak, N. ve Abdioğlu, Z. (2015). "Geriye ve İleriye Dönük Para Politikası Reaksiyon Fonksiyonlarının Tahmini: Taylor Kuralı". Süleyman Demirel Üniversitesi İktisadi ve İdari Bilimler Fakültesi Dergisi, 20(4), 141-163.

Alp, H., Baskaya, Y. S., Kilinc, M., ve Yuksel, C. (2011). “Turkiye için Hodrick-Prescott Filtresi Düzgünleştirme Parametresi Tahmini”. Türkiye Cumburiyet Merkez, Bankası Ekonomi Notlar, (No. 1103):1-8.

Ardor, N. H. (2014). "İleriye Dönük Yeni Keynesyen Para Politikas1 Reaksiyon Fonksiyonunun Tahmini"., Ekonomik Yaklassm. 24(89):45-71.

Bal, H., Tanriöver, B. ve Erdoğan, E. (2016). “Taylor Kuralı Kapsamında Merkez Bankası Politika Faiz Oranlarının Belirlenmesi: Stokastik Trend Yaklaşımı", International Journal of Academic V alue Studies, 2 (6): 95-106.

Ball, L. (1999), "Policy Rules for Open Economies." Taylor, J. (Ed.), Monetary Policy Rules, Chigago: University of Chigago Press, 127153.

Bec, F., Salem, M. B. ve Collard, F. (2002). Asymmetries in monetary policy reaction function evidence for the U.S., French and German central banks. Studies in Nonlinear Dynamics \& Econometrics, 6(2):126.

Boehm, C. E. ve House, C. L. (2019). "Optimal Taylor Rules when Targets are Uncertain”. European Economic Review, 119:274-286.

Bunzel, H. ve Enders, W. (2010). "The Taylor Rule and "Opportunistic" Monetary Policy", Creates Research Paper, 4:1-30. 
Caporale, G. M., Helmi, M. H., Çatık, A. N., Ali, F. ve M., Akdeniz, C. (2018). "Monetary Policy Rules In Emerging Countries: Is There An Augmented Nonlinear Taylor Rule?". Economic Modelling, 72:306-319.

Chen, C., Yao, S., ve Ou, J. (2017). "Exchange Rate Dynamics İn A Taylor Rule Framework". Journal of International Financial Markets, Institutions and Money, 46:158-173.

Chevapatrakul, T. , Mizen, P. ve Kim, T., (2002). "Predicting Changes in The Interest Rate: The Performance of Taylor Rules Versus Alternatives For The United Kingdom", bttp// repec.org./ res2016/kimTH.pdf.

Clarıda, R., Galı, J. ve Gertler, M. (1998). "Monetary Policy Rules in Practice Some International Evidence". European Economic Review, 42(6): 1033-1067.

Cuestas J. C. ve Garrant, D. (2011), "Is Real GDP Per Capita a Stationary Process? Smooth Transitions, Nonlinear Trends and Unit Root Testing", Empirical Economics, 41:555-563.

Çağlayan, E. ve Astar, M. (2011). "Faiz Oranı Hareketleri Üzerinde Enflasyon Açı̆̆ı, Üretim Açı̆̆1 Ve Döviz Kuru Açı̆̆ının Etkisi”. Trakya Üniversitesi Sosyal Bilimler Dergisi, 13(2):69-87.

Demirbaş, E. ve Kaya, V. (2012),. "Testing The Valıdıty Of Taylor Prıncıple For Turkey From A Different Perspective", AIBÜ Sosyal Bilimler Enstitüsü Dergisi, 2012, Cilt:12, 20. Yul, Özel Sayı, 12:81-110.

Dolores R.M. ve Vazquez J. (2004). “The New Keynesian Monetary Models: Does It Show The Comovement Between Output and Inflation in The US?", De Gruyter, 6(2), 1-37.

Dolares, R. M. (2005); "Monetary Policy Rules In Accession Countries to EU: Is the Taylor Rule a Pattern?” Economics Bulletin, C.5, No.5.

Gerdesmeier, D. ve Roffia, B. (2004); “Taylor Rules For The Euro Area:The Issue of Real-Time Data" Deutsche Bundesbank Discusion Papers Series 1:Studies of The Economic Research Centre, No.37.

Gerlach, S. ve G. Schnabel. (2000). "The Taylor Rule and Interest Rates in the EMU Area”. Economics Letters, 67:165-171.

Greiber, C., ve Herz, B., (2000). "Taylor Rules in Open Economies",.Working Paper Bayreuth University.

Gujarati, D. N. (2009), Temel Ekonometri, İstanbul: Literatür Yayınc1lık. 
Hodrick, R. J. ve Prescott, E.C.(1997). "Postwar U.S. Business Cycles: An Empirical Investigation". Journal of Money, Credit and Banking, 29, 116.

Gascoigne, J. ve Turner, P. (2004). "Asymmetries in Bank of England monetary Policy". Applied Economics Letters, 11:10:615-618.

Judd, J. P. ve Rudebusch, G. D. (1998). “Taylor's Rule and the Fed, 19701997”. Federal Reserve Bank of San Francisco, Economic Review, No:3: 316.

Kamin, S.B. ve Rogers, J.H. (1996). "Monetary Policy in the End-Game to Exchange- Rate Based Stabilizations: The Case of Mexico". Journal of International Economics, 41:285-307.

Kapetanios G., Shin Y. and Snell A. (2003). "Testing for a Unit Root in the Nonlinear STAR Framework", Journal of Econometrics, 112, 359-379.

Kesriyeli, M. ve Yalçın, C. (1998). "Taylor Kuralı ve Türkiye Uygulaması Üzerine Bir Not", TCMB Arasstrma Genel Müdürlï̈ü̈, Tartısma Tebliği, No:9802.

Kozicki, S., (1999). "How Useful Are Taylor Rules for Monetary Policy". Federal Reserve Bank of Kansas City Economic Review, Second Quarter.

Leiderman, L, Maino, R. ve Parrado, E. (2006). "Inflation Targeting in Dollarized Economies”, IMF Working Paper, 157.

Yazgan, M.E. ve Yilmazkuday, H. (2007). "Monetary policy rules in practice: evidence from Turkey and Israel". Applied Financial Economics, 17:1, $1-8$.

Mankiw, N. G. (2010) Makroekonomi, (Çev. Ö. F. Çolak), Efil Yayınevi, Ankara.

Markov, N. ve Nitschka, T. (2013). "Estimating Taylor Rules for Switzerland: Evidence from 2000 to 2012", Swiss National Bank Working Papers, 8.

Mehra, Y. P. (1994). “A Federal Funds Rate Equation”. Federal Reserve Bank of Richmond Working Paper.

Nelson, E. (2000).“UK Monetary Policy 1972-97: a Guide using Taylor Rules”.,Bank of England Working Paper, No:20.

Orlowski, L. T. (2010). "Monetary Policy Rules for Convergence to the Euro", Economic Systems,3 4(2), 148-159.

Österholm, P. (2005). “The Taylor Rule: A Spurious Regression?” Bulletin of Economic Research, 53(3): 217-247. 
Özçam, M. (2004). Enflasyon Hedeflemesi, Sermaye Piyasası Kurulu Araştırma Raporu, 23.

Pesaran, M. H., Shin, Y., ve Smith, R. J. (2001). "Bounds testing approaches to theanalysis of level relationships". Journal of Applied Econometrics, 16(3): 289-326.

Phillips, P. C. B. ve Perron, P. (1988). "Testing for a Unit Root in Time Series Regression". Biometrika, 75(2):335-346.

Shibamoto, M. (2008). "The Estimation of Monetary Policy Reaction Function in a data-rich environment: The case of Japan".Japan and the World Economy, 20(4):497-520.

Shin Y., Yu B., Greenwood-Nimmo M. (2014) "Modelling Asymmetric Cointegration and Dynamic Multipliers in a Nonlinear ARDL Framework" Sickles R., Horrace W. (Eds), Festschrift in Honor of Peter Schmidt. Springer, New York, NY, 281-314.

Sollis, R. (2009), “A simple unit root test against asymmetric STAR nonlinearity with an application to real exchange rates in Nordic countries", Economic Modelling, 26: 118-125.

Taylor, B. J. (1993). "Discretion Versus Policy Rules in Practice". CarnegieRochester Conference Serieson Public Policy, 39:195-214.

Taylor, B. J. (2001). "The Role of the Exchange Rate in Monetary Policy Rules". The American Economic Review, 91 (2), 263-267.

Taylor, J. B. (1998). “An Historical Analysis of Monetary Policy Rules”. National Bureau of Economic Research Working Paper, Vol. 6768.

Taylor, J. B. (1993). "Discretion versus Policy Rules in Practice", CarnegieRochester Conference Series on Public Policy, Vol. 39:195-214.

TCMB, (2005). Enflasyon Hedeflemesi Rejiminin Genel Cerçevesi ve 2006 Yllinda Para ve Kur Politikası. Türkiye Cumhuriyet Merkez Bankası, Ankara.

TCMB, (2013a). Enflasyon ve Fiyat Istikrar. Türkiye Cumhuriyet Merkez Bankasi, Ankara.

TCMB, (2013b). Parasal Aktarm Mekanizması. Türkiye Cumhuriyet Merkez Bankasi, Ankara.

TCMB, (2019). 100 Soruda Merkez Bankacılı̆̆. Türkiye Cumhuriyet Merkez Bankasi, Ankara.

Ünsal, E. M., (2017). Makro İktisat. Murat Yayınları, Ankara. 
Vasicek, B. (2009). "Monetary Policy Rules and Inflation Process in Open Emerging Economies: Evidence For 12 New EU Members". William Davidson Institute Working Paper, 968.

Wang, R., Morley, B., ve Ordonez, J. (2016). “'The Taylor Rule, Wealth Effects And The Exchnage Rate". Review of International Economics, 24:282-301. 